مستوى الجدية يج العمل التربوي والولاء التنظيمي لدى معلمي المدارس الثانوية الحكومية يِ فلسطين

غسان حسين الحلو

ghhilo@najah.edu

جامعة النجاح الوطنية

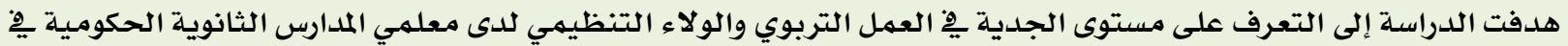
فلسطين، إضافة إلى استقصاء أثر متغيري النوع الاجتماعي وسنوات الخبرة، والتفاعل بينهما لدى المعلمـين. ولتحقيق ذلك

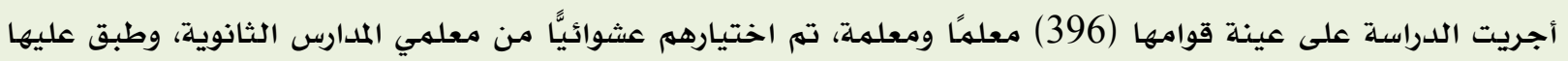
استبانة لقياس مستوى الجدية يِ العمل التربوي والولاء التنظيهي، والتي تكونت من (70) فقرة، منها (42) فقرة لقياس مستوى الجدية يِّ العمل التربوي، موزعة على مجالات الدراسـة، إضافة إلى (28) فقرة لقياس مستوى الولاء التنظيمي.

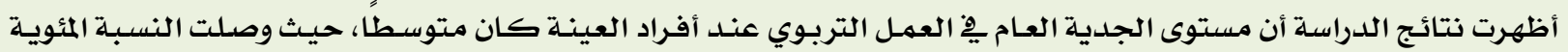

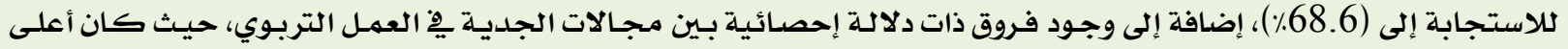

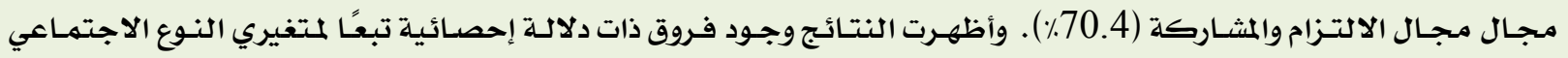
وسـنوات الخـبرة، والتفاعل بينهما ِِِ مـجـال الالتـزام والمشـاركة، ولصـالح المعلمـات ذوات سـنوات الخبرة الطويلـة؛ومـتغير النـوع الاجتماعي والتفاعل بين متغيري النوع الاجتماعي وسنوات الخبرة ِِّ مجـال السـيطرة والتحكمه، ولصـالح المعلمـين مـن أصـحاب

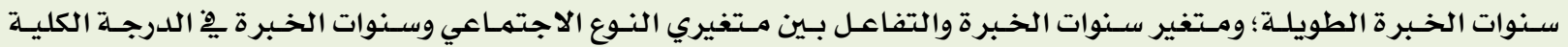

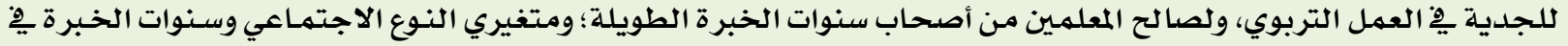
الدرجـة الكلية للولاء التنظيهـي، ولصـالح المعلمـات مـن ذوات سـنوات الخبرة الطويلـة.وبنـاء على نتـائسج الدراسـة، أوصى الباحـث

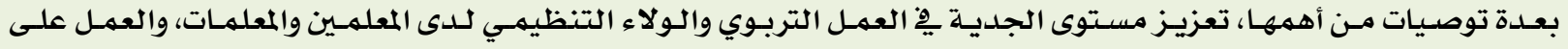
الحفاظ عليها وتنميتها باستمرار.

\title{
Hardiness Behavior and Organizational Loyalty of Government Secondary School Teachers in Palestine
}

Ghassan H. Hilo

An-Najah National University

The purpose of this study was to a) investigate hardiness behavior and organizational loyalty levels among secondary school teachers in the northern districts of the West Bank in Palestine and b) determine the effect of teachers' gender and years of experience. The sample consisted of 396 male and female secondary school teachers, which were selected randomly from the target population. The questionnaire used in the study contained 42 items on hardiness behavior domain and 28 items for organizational loyalty domain. The results indicated that there was a moderate level of hardiness behavior among teachers $(68.6 \%)$. Also, the results revealed that there were statistically significant differences due to gender and years of experience in commitment and participation items in favor of longer teaching experience. There were also statistically significant differences due to gender, and interaction between gender and years of experience, in control items in favor of males with longer teaching experience. There were significant differences due to years of experience, and interaction between gender and years of experience in the overall degree of hardiness behavior, in favor of longer teaching experience. There were significant differences due to gender and years of experience in the overall degree of organizational loyalty domain in favor of females with longer teaching experience.

The researcher recommended the reinforcement of hardiness behavior and organizational loyalty levels among Palestinian teachers. 
الظروف والإمكانات المتاحة التي تساعد على تحقيق الأهداف التزبوية المرجوة بنجاح. ولتحقيق هذا الغرض لا بد من الارتقاء بمستوى أداء المعلم

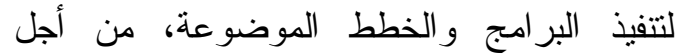
تحسين العملية التعليمية التعلمية، وضمان تحقيق الأهداف النبيلة الني يسعى النظام التربوي إليها بمهارة وكفاية و إتقان (عطوي، 2001). ولكي يسنطيع المعلم أن يقوم بالدور المناط بهابه

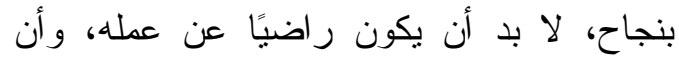

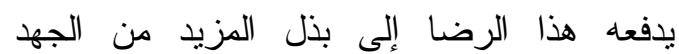
و العطاء، و الإخلاص و الجدية في العمل، ويدفعه البها. الرضا أن يكون أكثر انتماء وورلاءً لمهنته

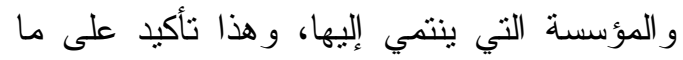

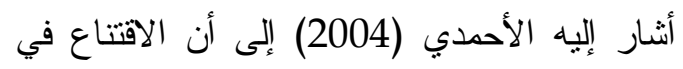

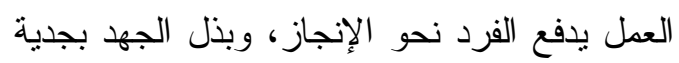
وو لاء. فمن هنا يمكن القول أنه حتى ينجح المعلم

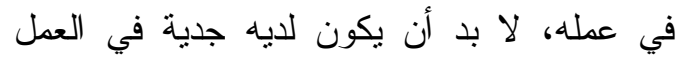
(Hardiness)

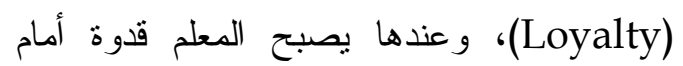

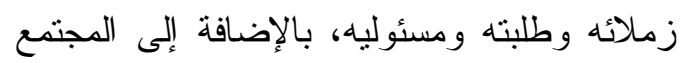

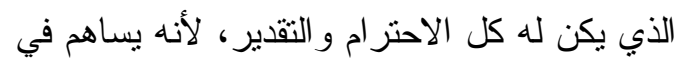
تطويره من خلا وظيفته في حقل التربية و التعليم، وذللك لإسهامه الايجابي في نربية النشء من ونه وتعليمه من أبناء المجتمع الذي ينتمي إليه. وبالنسبة للجدية في العمل، فقد عرفها مادي لئه وكوباسا (Maddi \& Kobasa, 1984) بالسمة الثخصية التي تساعد الفرد المنتج في التخلص

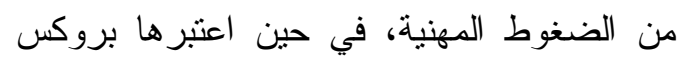
بأنها إحدى الجوانب المفيدة (Brooks, 1999)

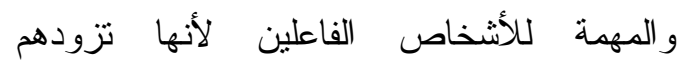
بخصائص الثخصية المميزة، كالتحكم والتحدي و الالتز ام. أما هيثز وجيل ) Heather \& Gail, بهيل

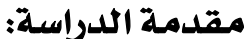

حظي موضوع الجدية في العمل باهتمام الباحثين في السنوات القليلة الماضية، وذلك نظرًا للعلاقة الوثثقة التي ترتبط ما بين الجدية في العمل و القدرة على زيادة الإنتاج، وخاصة في مجالي لزيط لئل السلوك النتظيمي و علم النفس الصناعي، ثم انتقل الاهتمام به لاحقًا إلى المؤسسات التربوية، حيث النئ

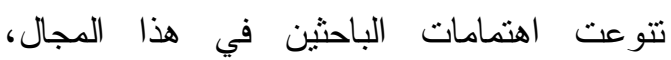
وغطت مجالاً واسعًا من المؤثرات التي تؤثر

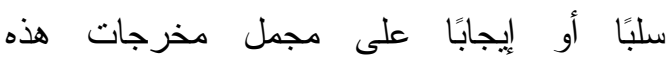

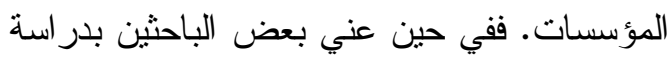

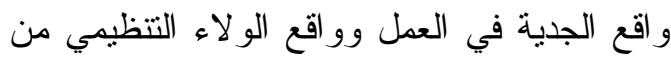
حيث تأثير هما على زيادة الإنتاجية عند العاملين،

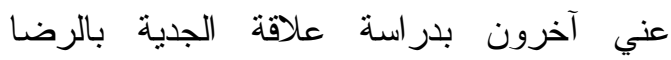

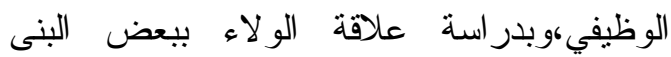
التنظيمية الافتراضية، منل الفاعلية و والدافعية

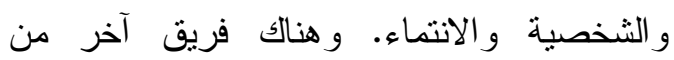
الباحثين اهتم بآثار الجدية في العمل و آثار الولاء

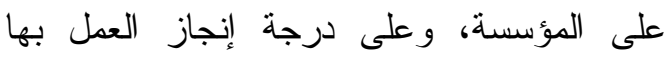
وحمايتها من مظاهر السلوك السلبية، منل التغيب

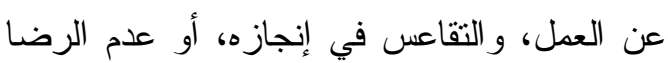

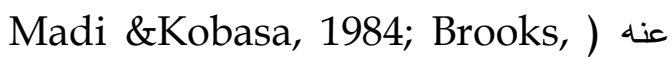
1999؛ مصطفى، 1993؛ غنام، 2005؛ القاروط، 2006). ونظرًا للعلاقة الوطيدة التي ترنبط ما بين جدية

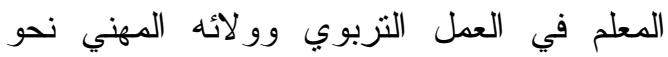
المؤسسة التي ينتمي إليها، فإن الأمر يقتضي وليدي

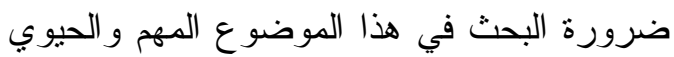
للنهوض بالمستوى المهني للمعلم، على اعتبار أنه

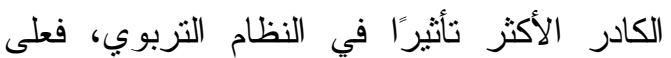
كاهله يقع العبء الأكبر في توفير مختلف 
الاعتقاد الراسخ بقبول قيم المؤسسة وأهدافها،

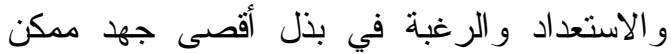
لصالح المؤسسة، و الرغبة الجادة في المحافظة

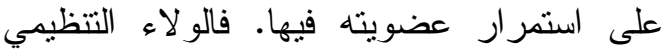
بهذا المعنى، كما ير اه البكري (1990) يعد بمثابة الاستثمار المنبادل بين الفرد و المنظمة، و المتمنل لئل باستمر ارية العلاقة التعاقدية بينهما، بحيث يترتب عليه سلوك الفرد سلوكاً يفوق السلوك الرسمي المتوقع من جانب المنظمة، ورغبة الفرد في إعطاء جزء أكبر من وقته وجهده من أجل الإسهام في تحقيق الأهداف المرجوة التي تسعى المنظمة إليها، كالاستعداد للتضحية من وقته لمصلحة المنظمة، وبذل مجهود أكبر من العمل الجاد و القيام بأعمال تطوعية وتحمل مسؤوليات

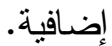
أما الفهداوي و القطاونة (2004) فقد شبها الو لاء التنظيمي بالاقتران الفعال بين الفرد و المنظمة، بحيث يبدي الموظف الموالي للمنظمة الرغبة الصادقة في خدمتها، برغم حصوله على مردود أقل. فالو لاء التتظيمي، كما يتصوره المختصون،

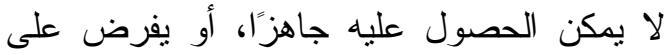
الأشخاص فرضنًا بوسائل الاكر اه المختلفة، بل هو محصلة للكثير من العو امل و المتغير ات المتشابكة، و أن من أهمها البناء النفسي للفرد تجاه المؤسسة التي يعمل بها عندما يبذل من وقته وجهده الثيء الثيء الكثير من أجل خدمتها، والإسهام في الرفع من لناع شأنها. وفي السياق ذاته، يحدد الأحمدي (2004) أهم المرنكزات التي توضح الملامح التي تدل على التى الولاء التتظيمي، و التي أمكن حصرها في ثناثة

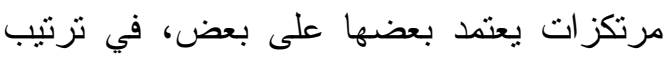

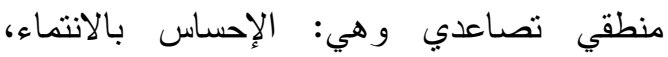
و الإسهام الفاعل بالعمل على تفعيل هذا الانتماء،

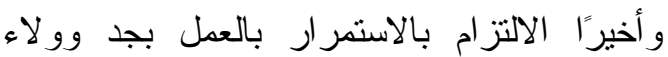

1988)، و إنفولدسن وداون ( Enevoldsen \& (Dawn, 1995 الثخصية تؤنز جليًّا في كفاءة وفاعلية ودوافع

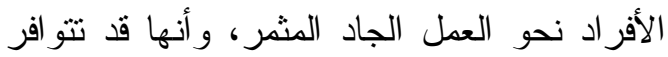
في بعض الأفراد، لكنها لا تتو افر بجميع الأفراد اد واد التهاد إلا في أصحاب الثخصيات الفذة، كما أنهم توصلوا إلى أن بعض المتغيرات، كالجنس وسنوات الخبرة والاعنقادات المهنية، تلعب دورًا حاسمًا في التأثثر على كفاءة الفرد وجديته تجاه العمل. أما كوباسا (Kobasa, 1983)، فقد بين أن الجدية في العمل تشتمل على ثلاثة مجالات تظهر ملامحها في سلوك الفرد، وهي: أولاًا الالتز ام و المشاركة (Commitment)، ويتمنل بالقدرة على الاشتر الك بأنشطة إيجابية و المشاركة بها بفاعلية بدلاً من الانعز ال و الوحدة، و القدرة على تحديد الأهداف وتتظيمها. و المجال الثاني هو مجال التحدي و التغيير (Commitment)، ويتمثل بقدرة الفرد على التغيير بما يو اكب المستجدات في صعيد العمل، أما المجال الثالث فهو مجال السيطرة والتحكم (Control)، ويتمنل بقدة الفرد على توجيه العمل بفاعلية بدلاً من

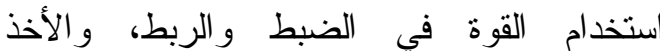
و العطاء.

Organizational ( وبالنسبة للو لاء التتظيمي Loyalty (Porter, Steers \& Mowday, 1974) أبرز الباحثين الذين اهتموا بموضوع الولاء التنظيمي وماهيته، حيث عرفوا الولاء النتظيمي بمدى قوة اندماج الفرد مع المنظمة التي يعمل في إطار ها، وأوضحوا أن الفرد الذي يمنلك انتماء ووفاء للتتظيم الذي يعمل به يتمتع بحالة مرضية

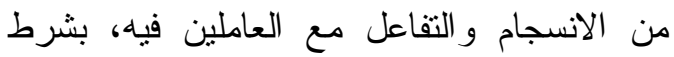
توفر مجموعة من الصفات التي يمكن بموجبها ونها تحديد مستوى الولاء لديه، ومن هذه الصفات: 
حول أهمية مراعاة العلاقة بين الجدية في العمل التربوي و الولاء التنظيمي عند

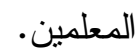

2. تعد الدراسة الحالية - في حدود علم الباحث - الأولى في فلسطين التي تهتم بدراسة العلاقة بين الجدية في العمل الثربوي و الولاء التظظيمي عند المعلمين في فلسطين. 3. يتوقع من خلال نتائج الدراسة التعرف على لى لى تأثثر منغيري النوع الاجتماعي وسنوات لـات الخبرة، و التفاعل بينهما، على مستوى الجدية في العمل التزبوي والولاء التنظيمي عند معلمي المدارس الثانوية الحكومية في في لهية مديريات محافظات شمال الضفة الغربية في فلسطين. 4. يتوقع أن تستقيد وزارة التزبية و التعليم العالي

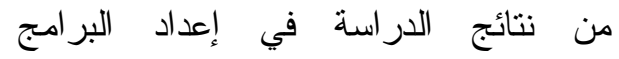

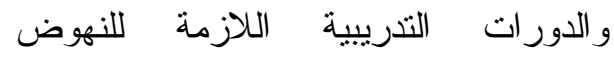
بمستوى الجدية في العمل التربوي و الولاء عند المعلمين تجاه مؤسساتهم التعليمية.

أهداف الدراسة:

سعت الدراسة إلى تحقيق الأهداف الآتية: 1. التعرف إلى مسنوى الجدية في العمل

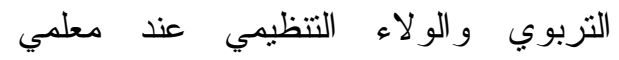
المدارس الثانوية الحكومية في مديريات محافظات شمال الضفة الغربية في فلسطين. 2. التعرف إلى أثز متغيري النوع الاجتماعي

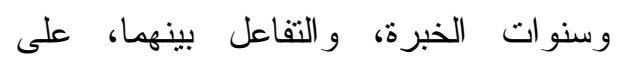
مستوى الجدية في العمل التربوي و الولاء التنظيمي عند معلمي المدارس الثانوية الحكومية في مديريات محافظات شمال الضفة الغربية في فلسطين.
واخلاص، وبالتالي يمكن الجزم بأن الفرد لا يقوم بمنح و لاءه لمنظمته دفعة واحدة بدون مؤثرات، بل لا بد أن يتو افر لديه محفزات نتمي لديه

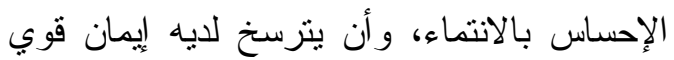
بأهداف منظمته وقيمها، وأن يتبلور لايه الاستعداد لبذل أقصى جها ممكن للحفاظ على ما حققته المنظمة من أهداف، وأن يدعم رغبته الصادقة في الحفاظ على استمر ارية عضويته فيها. ومن خلال ما سبق ذكره حول العلاقة بين الجدية

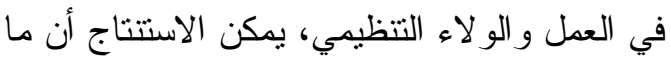
ينسحب من قول عن هذه العلاقة في المؤسسات الإنتاجية، ينسحب أيضًا على كوادر المؤسسات التربوية، و على رأسها معلم المدرسة الذي ييذل لإلئل من وقته وجهده الثيء الكثير نحو الارتقاء بأدائه المهني بجدية وانتماء وإخلاص، وهي وهي جميعًا

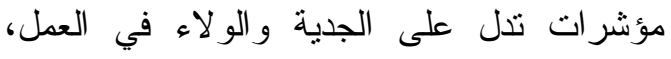
وبالنتيجة يمكن الاستخلاص أن العلاقة ما بين مفهومي الجدية في العمل و الولاء التتظيمي ما هي إلا علاقة تكاملية تعاونية نقوم على الإخلاص

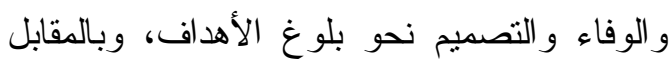
فإن تدني مستوى الجدية في العمل قد يعد مؤشرًا

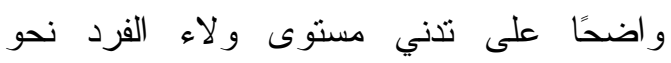
المؤسسة التي ينطوي في إطار ها.

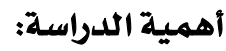

تأتي أهمية هذه الدراسة من الأهمية البالغة

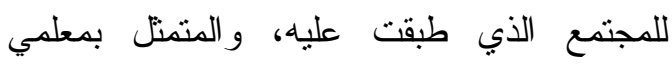
المدارس الثانوية في فلسطين، بالإضافة إلى أن هذه الدراسة تجمع بين الجدية في العمل التزبوي و الو لاء التنظيمي عند المعلمين. ويمكن إيجاز أهمية الدر اسة فيما يلي:

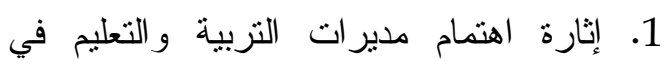
محافظات شمال الضفة الغربية في فلسطين 
و الاقتصادي الظالم الذي فرض على الثعب الفلسطيني في الآونة الأخيرة، الأمر الذي العكس على سلبًا على النظام التزبوي برمته، وفي فترة زمنية الاونه تعد الأخطر والأدق في حياة الثعب العربي لئربي الفلسطيني منذ نكبة عام 1948. وبالتحديد يمكن إيجاز مشكلة الدر اسة بالإجابة عن من ماته

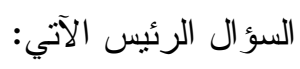
ما مستوى الجدية في العمل التربوي و الولاء التنظيمي لدى معلمي المدارس الثانوية الحكومية في مديريات محافظات شمال الضفة الغربية في فلسطين؟ وما مدى تأثز ها بمتغيري النوبات الاجتماعي وسنو ات الخبرة و التفاعل بينهما؟ وينبثق عن السؤال الرئيس السابق الأسئلة الفرعية

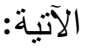
1. ما مستوى الجدية في العمل التربوي عند معلمي المدارس الثانوية الحكومية في لئية مديريات محافظات شمال الضفة الغربية في

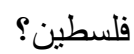

2. ما مستوى الولاء التتظيمي لدى معلمي المدارس الثانوية الحكومية في مديريات محافظات شمال الضفة الغربية في فلسطين؟ 3. هل هناك علاقة ارتباطية ذات دلالة إحصائية

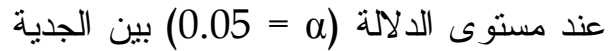
في العمل التربوي و الولاء التتظيمي عند

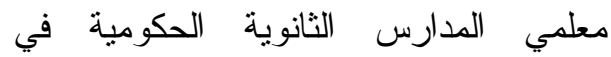
مديريات محافظات شمال الضفة الغربية في فلسطين؟ 4. هل هناك فروق ذات دلالة إحصائية عند

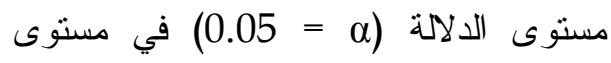
الجدية في العمل التربوي و الولاء التنظيمي عند معلمي المدارس الثانوية الحكومية في مديريات محافظات شمال الضفة الغربية في فلسطين تعزى لمتغير النوع الاجتماعي وسنو ات الخبرة و التفاعل بينهما؟
3. التعرف إلى العلاقة بين الجدية في العمل

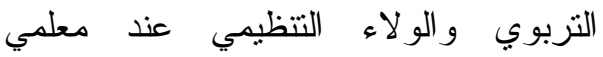
المدارس الثانوية الحكومية في مديريات محافظات شمال الضفة الغربية في فلسطين.

\section{مشكلة الدراسة وأسئلتها:}

انطلاقا من تقدير الباحث لأهمية الجدية في العمل

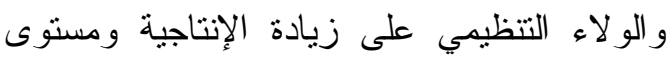
الانتماء لدى العاملين في المؤسسات، ارتأي

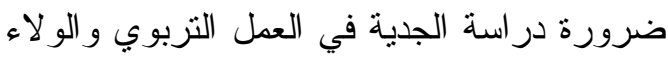
التنظيمي لاى معلمي المدارس الثانوية في فلسطين، لما لهذا الموضوع من أهمية قصوى لمعي

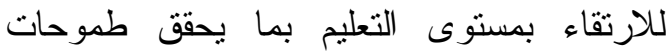

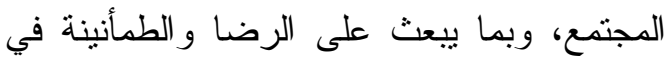

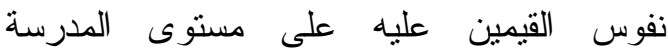
و المديرية. وحتى تكون هناك فاعلية في أداء المعلم، لا بد من توافر درجة عالية من الجدية و الولاء لديه نحو المدرسة التي ينتمي إليها، و هذا ما يؤكده الباحث لهذه الدراسة من خلال عمله المتصل بالمعلمين، حيث لاحظ أن المعلمين يختلفون في سلوكاتهر

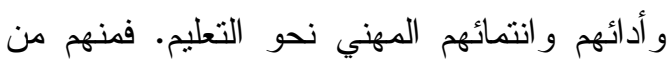
لديه جدية واضحة في عمله، وكفاءة وفاعلية في أدائه وسلوكه، وهو راض تمامًا عن عمله؛ ومنهم من هو غير ملتزم في عمله، ولا يشارك بأنشطة إيجابية في ددرسته ومجتمعه، وهو غير راضٍ عن عمله. وبناء على ما سبق ذكره، يرى الباحث أن هذه

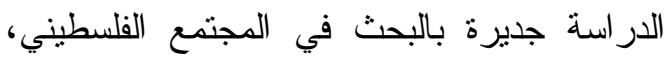
خاصة و أنها تتم في ظروف تتوبها بالجها أجواء غاية في الضبابية وعدم الرضا في أوساط المعلمين بسبب معاناتهم من الفوضى وعدم الانضباط التربوي في سلوك وتحصيل الطلبة في المدارس،

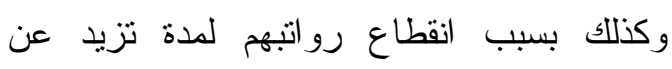
الخمسة عشرة شهرًا نتيجة للحصار السياسي رولي لردي 
المعلم على المشاركة بالأنشطة بفاعلية

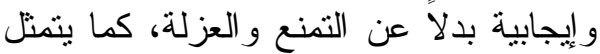
بالقدرة على تحديد الأهداف وتصويبها وتتظيمها ( \&cNeil, Stones, \& .(Hanna, 1986

مجال السيطرة و التحكم Control: ويتمثل بالقدرة على توجيه العمل بفاعلية عن طريق

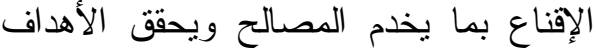
.(Allred \& Smith, 1989)

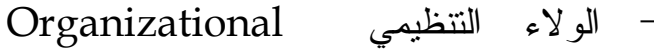
Loyalty Porter, Steers \& ) وبورتز (Mowday

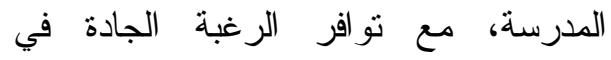

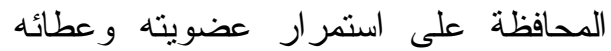
فيها نحو تحقيق الأهداف.

أما التعريف الإجر ائي لكل من الجدية في العمل لإلهر التزبوي و الو لاء التنظيمي، فيتمنل بالدرجة التي يحصل عليها المعلم المستجيب في استبانة الجدية في العمل التربوي والولاء التنظيمي المعدة من

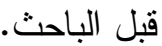

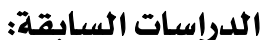

في ضو ء مر اجعة الأدب الثربوي المتعلق بالجدية

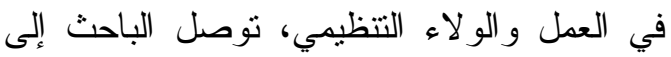

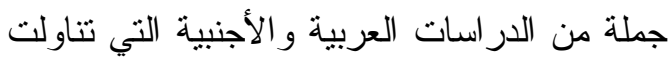
جو انب لها علاقة بالجدية في العمل، أو في الو لاء

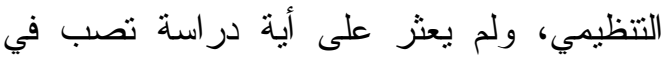

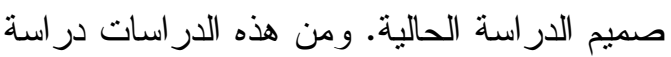
ريز وإمبر (Reyes \& Imber, 1992) التي حاولت التعرف على العلاقة بين إدرالك المعلمين لعدلالة عبء العمل والانتماء الوظيفي، وقد أجريت الدراسة على عينة شملت (472) معلمًا

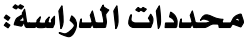

كما هو الحال في معظم الدراسات الميدانية، فإن لكل دراسة محداتها، ومحددات هذه الدراسة تتمثل في أنها التزمت في المحددات الآتية:

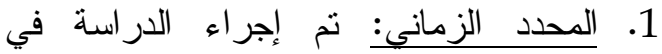
الفصل الثاني من العام الدراسي $.2007 / 2006$

2. المحدد البشري و المكانى: اقتصرت الدراسة على معلمي المدارس الثانوية الحكومية في مديريات محافظات شمال الضفة الغربية في فلسطين وهي: (نابلس، وجنين، وطولكرم، وقباطية، وقلقيلية، وسلفيت).

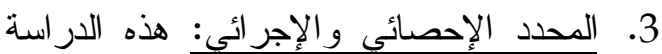

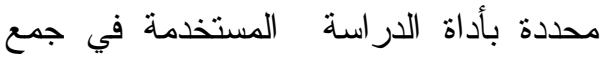
البيانات، وطبيعة التحليل الإحصائي المستخدم في معالجة البيانات، وفي ضوء المصطلحات الإجر ائية للار اسة.

مصسطلحات الدراسة:

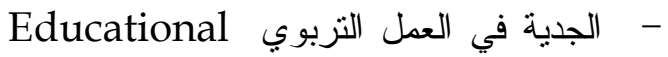
Hardiness الثخصية لمعلم، والتي تنساعده على التخلص من الضغوط المهنية التي تصادفه في مضمار العمل، وتشتمل على مجالات

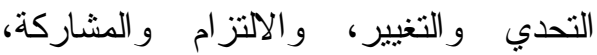

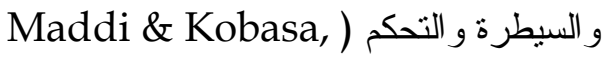
.(1984

Challenge and مجال التحدي و التغيير Change : ويتمنل بقدرة المعلم على التغيير

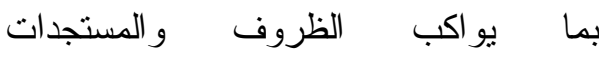
.(Brooks, 1999)

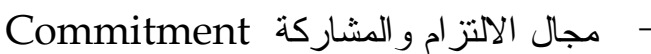
and Participation 
التنظيمي في ضوء مستويات المشاركة في اتخاذ القرارات المدرسية، وكانت عينة الدراسة مكونة

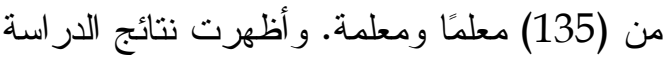

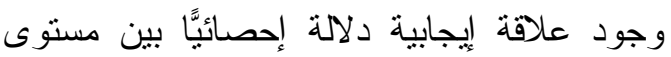
المشاركة في اتخاذ القرارات المدرسية والولاء التتظيمي لدى أفراد العينة، ووجود فروق ذات دلالة إحصائية في اتخاذ القرارات المدرسية بين المعلمين و المعلمات، ولصالح المعلمين و المعلمات ذوي المشاركة العالية في اتخاذ القرارات، في حين لا توجد فروق ذات دلالة إحصائية في اتخاذ

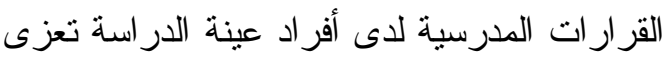
لمتغيرات الجنس، و المؤهل العلمي، بالإضافة إلى لى لـ عدم وجود فروق ذات دلالة إحصائية بين متوسطات استجابات المعلمين على مقياس الولاء التنظيمي تعزى لأثر التفاعل بين جنس المعلم ومؤهله العلمي. وقام القدومي (Qadumi, 2001) بإجر اء در اسة هدفت إلى التعرف على مستوى الجدية في العمل لاى معلمي ومعلمات اللغة الإنجليزية في مديريات محافظات شمال فلسطين، إضافة إلى تحديد دور كل من متغيرات النوع الاجتماعي، و المؤهل

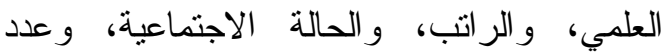
طلاب الصف، وسنوات الخبرة على مستوى الجدية في العمل على عينة بلغ قوامها (271) معلمًا ومعلمة، بعد أن طبق عليها مقياس مادي لهي وكوباسا (Maddi \& Kobasa, 1984) لقياس الجدية في العمل. وأظهرت النتائج أن مسنوى الجدية في العمل عند معلمي ومعلمات اللغة ولنة الإنجليزية في مديريات محافظات شمال فلسطين كان مرتفعًا بشكل عام، وبالنسبة لتزتيب المجالات

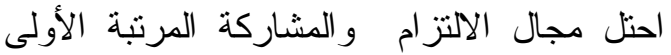
(\%77.2\%)، تلاه مجال السيطرة والتحكم (\%76.2\%)، وأخيرًا مجال التحدي و والتغيير (\%74.8)، وأظهرت النتائج وجود فروق ذات
ومعلمة من معلمي المدارس الثانوية في الو لايات المتحدة الأمريكية. وأظهرت النتائج وجود علاقة إيجابية ذات دلالة إحصائية بين إدرالك المعلمين لعدلالة عبء العمل و الانتماء المهني، كما أظهرت النتائج عدم وجود فروق ذات دلالة إحصائية في مستويات الانتماء المهني تعزى لمتغير ات الجنس، وسنوات الخبرة، وموقع المدرسة. أما ثومسون (Thomson, 1995) فقد أجرى دراسة هدفت إلى التعرف على العلاقة بين الجدية في العمل كخاصية شخصية وبين المناخ المدرسي

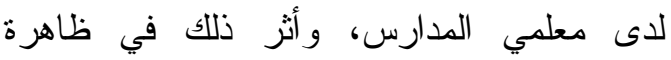
العزوف لدى الطلبة الذين يرغبون أن يصبحوا معلمين. وقد تكونت عينة الدر اسة من (106) معلمًا متوقعًا

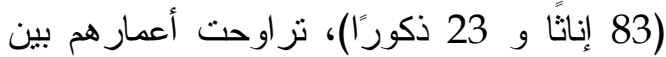
(21-40 سنة) من الذين وصلوا إلى المرحلة النهائية في برنامج إعدادهم لمهنة التعليم. و أنشارت النتائج أن المعلمين الذين تمتعو ا بمستوى عالٍ من

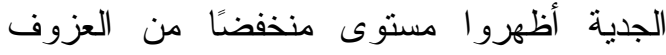
والنفور من المناخ المدرسي، فيما أبدى الذين أظهروا مستوى جدية أقل كان لديهم نفور أكبر

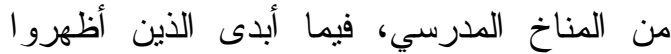
مستوى جدية أقل كان لديهم نفور أكبر من المناخ

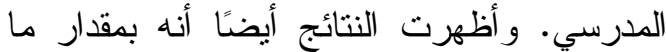
يكون مناخ المدرسة داعمًا للمعلم، بمقدار ما يكون المعلم الملتزم بالجدية في عمله أقل نفورًا من من مناح المناخ المدرسي، مقارنة بالزملاء ممن كانوا أقل

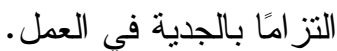

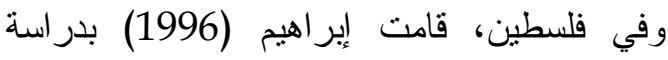
هدفت إلى التعرف على تأثثير مستوى مشاركة المعلمين للمديرين في اتخاذ القرارات المدرسية على الو لاء التنظيمي لاى معلمي المدارس الثانوية في مديرية محافظة بيت لحم، بالإضافة إلى بيان أثز كل من الجنس، والمؤهل العلمي على الولاء 
درجة الجدية في العمل و الرضا الوظيفي، وفي المقابل أثنارت نتائج الدراسة إلى عدم وجود فروق دلالة إحصائيًا في درجة الجدية في العمل تعزى لمتغيرات النوع الاجتماعي، و المؤهل العلمي، وسنوات الخبرة، و الراتب الثهري، وموقع المدرسة، ومستوى المدرسة. وقامت السلعوس (2007) بدراسة هدفت إلى فلى التعرف على العلاقة بين السمات الثخصية و الانتماء التنظيمي عند معلمي المدارس الخاصة

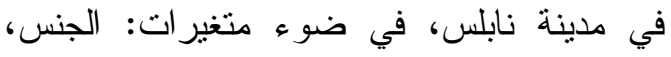
وسنوات الخبرة، والتخصص، و المؤهل العلمي، و العمر ، وتألفت عينة الدراسة من (154) معلمًا

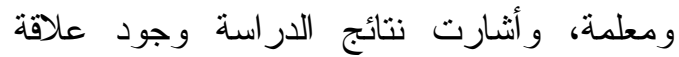
ارتباطية دلالة إحصائًّا بين السمات الثخصية

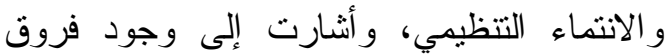
ذات دلالة إحصائية في السمات الثخصية تعزى لمتغير المؤهل العلمي، ولصالح أصحاب المؤهل العلمي بدرجة بكالوريوس فأعلى من المعلمات. ومن خلال ما سبق عرضه من دراسات، تتضح بله أهمية دراسة الجدية في العمل التربوي و الولاء التتظيمي لاى معلمي المدارس في فلسطين، من خلال التعرف على مستوى الجدية و الولاء التتظيمي لديهر نحو المؤسسات التي ينتمون إليها،

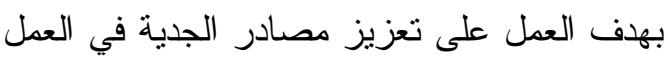
الجاد و المثمر و الهادف، خدمة للنظام التزبوي في لهري لهني فلسطين، على اعنبار أن المعلم يمثل أحد أهم

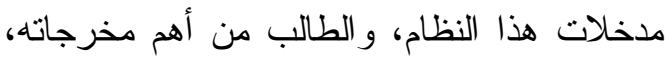

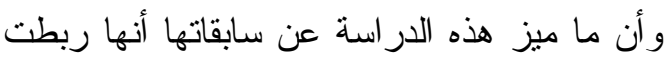
بين الجدية في العمل و الو لاء التنظيمي لدى معلمي المدارس الثانوية الحكومية في مديريات محافظات شمال الضفة الغربية في فلسطين.

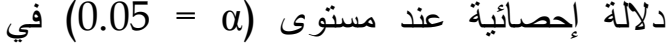
مجال الالتزام و المشاركة ولصالح المعلمات، ومجال التحدي و التغيير ولصالح أصحاب سنوات الخبرة المتوسطة، ومجال السيطرة و التحكم و لأصحاب سنوات الخبرة الطويلة، في حين لم

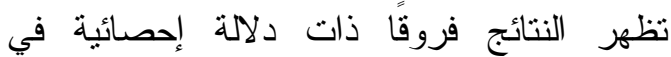
مسنوى الجدية في العمل تعزى لمتغيرات الراتب، و المؤهل العلمي، وعدد طلاب الصف، و الحالة الاجتماعية لأفر اد عينة الدراسة. وفي دراسة قام بها سومنت وبوكلر ( Somech (\& Bogler, 2002 بهدف التعرف إلى العلاقة بين الو لاء التتظيمي للمعلمين و المشاركة في اتخاذ القرار على عينة بلغت (983) معلمًا من (25) مدرسة أساسية و (27) مدرسة ثانوية في تركيا، و أظهرت نتائج الدر اسة وجود ارتباط إيجابي دال إحصائيًا بين الولاء التنظيمي والمجال الإداري و الحضاري المنظم في التعامل مع التلاميذ و الزملاء في المدرسة، و أظهرت النتائج وجود ارتباط إيجابي دال إحصائيًا بين الولاء التنظيمي

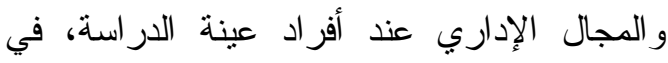
حين لا توجد فروق ذات دلالة إحصائية في الولاء

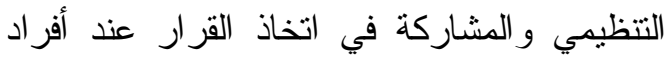
عينة الدراسة تعزى للجنس، وسنوات الخبرة، و المؤهل العلمي. أما القاروط (2006) فقد أجرى در اسة هدفت إلى التعرف على مستوى الجدية في العمل وعلاقتها بالرضا الوظيفي لاى مديري المدارس الحكومية في فلسطين، على عينة بلغت (221) مديرًا ومديرة في مديريات محافظات شمال فلسطين. و أظهرت نتائج الدراسة أن درجة الجدية في العمل ملايل لدى المديرين كانت كبيرة، في حين كانت درجة الرضا الوظيفي عند المديرين منوسطة، و أظهرت النتائج وجود علاقة ارتباطية دلالة إحصائيًا في 


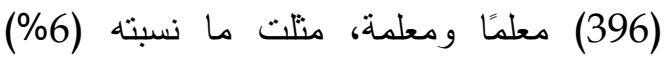

منهجية الدراسة:

تقريبًا من مجتمع الدراسة، حيث نم اختيارها بالطريقة العشوائية الطبقية المنتظمة من المدارس

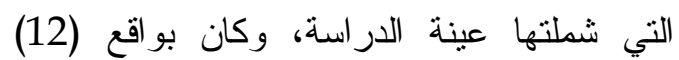
معلمًا أو معلمة من المدرسة الواحدة. وجدول رقما فئة

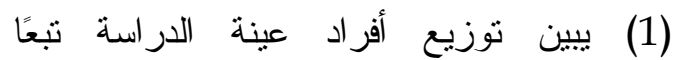
للمتغير ات المستقلة التي تتاولتها الدراسة وهي: النوع الاجتماعي (ذكر، أنثى)، وسنوات الخبرة

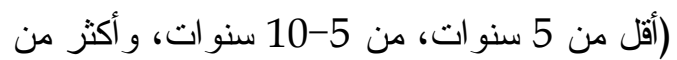

$$
10 \text { سنو ات). }
$$

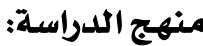

استخدم الباحث المنهج الوصفي بأحد صوره المسحية الملائمة لأغر اض الدراسة.

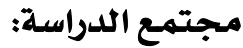
تكون مجتمع الدراسة من معلمي المدارس الثانوية

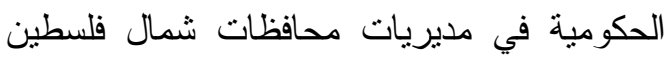
وهي: (نابلس، وجنين، وطولكرم، و وقلقيلية، وسلفيت)، و البالغ عددهم (6399) معلمًا ومعلمة.

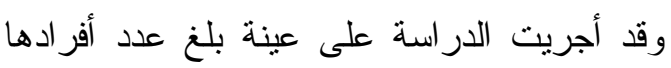

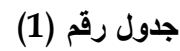

وصف عينة الاراسة تبعًا لمتفيري النوع الاجتماعي وسنوات الخبرة

\begin{tabular}{|c|c|c|c|c|c|c|c|c|}
\hline \multicolumn{2}{|c|}{ المجموع } & \multicolumn{2}{|c|}{ أكثر من 10 سنوات } & \multicolumn{2}{|c|}{ من 5-10 سنوات } & \multicolumn{2}{|c|}{ أقل من 5 سنوات } & الذا \\
\hline$\%$ & ت & $\%$ & ت & $\%$ & ت & $\%$ & ت & النوع \\
\hline 38.4 & 152 & 21.0 & 83 & 12.3 & 49 & 5.1 & 20 & ذكر \\
\hline 16.6 & 244 & 25.2 & 100 & 15.2 & 60 & 21.2 & 84 & أنثى \\
\hline$\% 100$ & 396 & 46.2 & 183 & 27.5 & 109 & 26.3 & 104 & المجموع \\
\hline
\end{tabular}

وقام الباحث بإجر اء دراسة استطلاعية شملت (22) طالبًا وطالبة من طلبة برنامج الدراسات

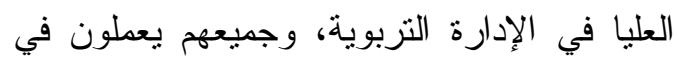
حقل التعليه، مما ساعد على تجميع الكثير من لين البيانات المتعلقة باستبانة الدر اسة. وقد تكونت أداة الدراسة من جزأين: الأول و اشتمل على معلومات ديموغر افية عامة تتعلق بالمعلمين من حيث النوع الاجتماعي، وسنوات

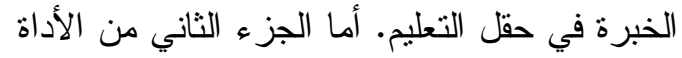
فتكون من قسمين، الأول ويتعلق بفقرات مقياس الجدية في العمل التربوي بمجالاتها الثلاثة و عددها (42) فقرة، والثاني ينعلق بمجال مقياس الو لاء النتظيمي وعدد فقر اته (28) فقرة.

صدق أداة الدراسة:

للتحقق من صلاحية أداة الدراسة في قيام ما مادمان صمدت لقياسه، تمكن الباحث من التوصل إلى في فئ

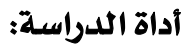

لتحقيق أغراض الدراسة قام الباحث بترجمة الدام Kobasa, ) استبانة كوباسا ومادي وكاهان Maddi \& Kahan, 1982 و التي تنعلق بالجدية في العمل، بعد أن قام الباحث بإجراء

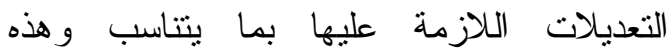
الأغراض، وقام الباحث بالإطلاع على الأدب التزبوي، بالإضافة إلى الاستفادة من دراسة الإنة

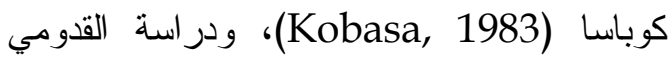

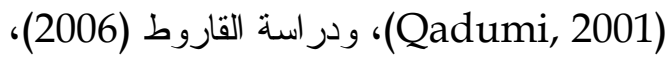
وجميعها تتعلق بالجدية في العمل. وبالنسبة للجزء

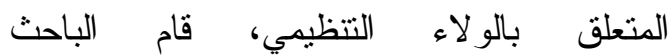

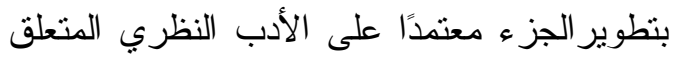

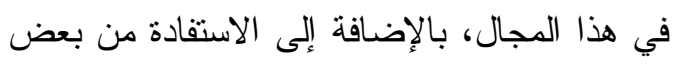

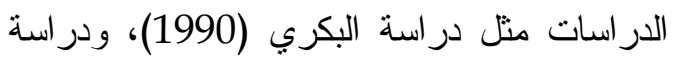
الأحمدي (2004)، ودر اسة غنام (2005). كما 
النهائية من (70) فقرة، وهي التي تم اعتمادها وتوزيعها على أفر اد عينة الدر اسة.

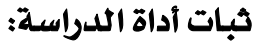

للتحقق من ثنات أداة الدراسة، قام الباحث باستخدام معادلة كرونباخ ألفا لقياس الاتساق الداخلي بين مجالات الأداة، بالإضافة لاستخر اج قيمة الثبات محسوبة على أساس الدرجة الكلية للجدية في العمل التزبوي و الولاء التتظيمي، وجدول رقم (2) يوضح ذلك.

دلالة صدق محتوى عن طريق عرضها على (9) محكمين من الخبر اء و المختصين في التزبية وعلم النفس في كلية العلوم التربوية بجامعة النجاح الوطنية، بالإضافة إلى عرضها على (4) مشرفين تربويين (2 ذكور، 2 إناث) ممن أمضوا ما لا لا لإلى يقل عن (25) سنة في حقل الإشر اف والتعليه، وفي ضوء الملاحظات و المقترحات من قبل المحكمين، قام الباحث بإجر اء التعديلات المناسبة التي أجمع (80\%) منهم على ملاءمتها، وبذللك أصبحت أداة الدراسة بقسميها تتكون في صورتها

جدول رقم (2)

قيم معاملات الثبات لمجالات الجدية في العمل التربوي والارجة الكلية، وقيمة الثبات الكلي لمجال الولاء التنظيمي باستخدام معادلة كرونباخ - ألفا

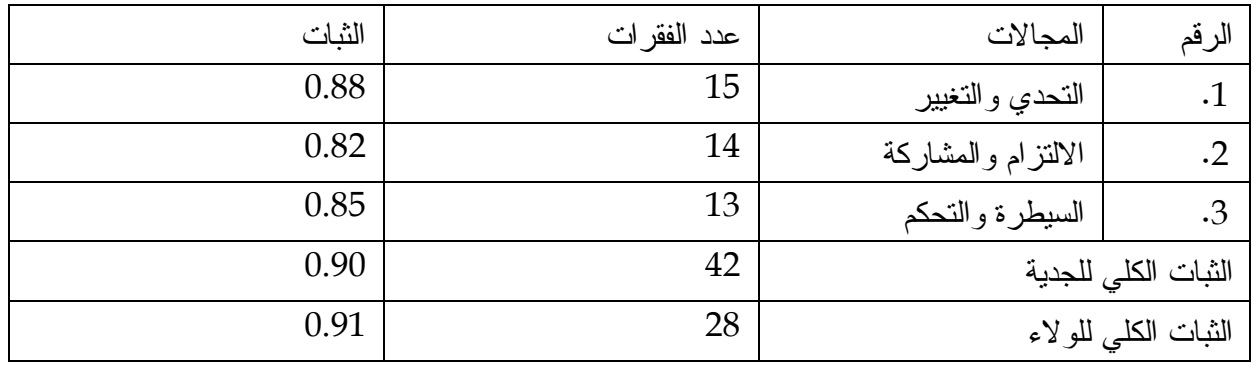

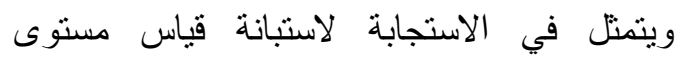

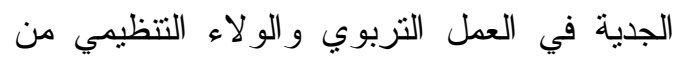

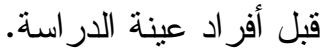

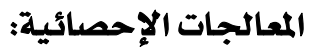

من أجل الإجابة عن أسئلة الاراسة، استخدم الباحث برنامج الرزم الإحتهائية للعلوم الاجتماعية (SPSS)، وذللك باستخدام الأساليب

$$
\text { الإحصائية الآتية: }
$$

1. المتوسطات الحسابية، و النسب المئوية لأداء أفراد عينة الدراسة على استبانة

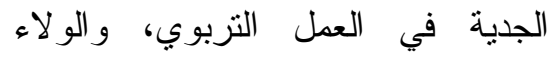

$$
\text { التظظيمي. }
$$

2. تحليل التباين متعدد المتغيرات التابعة

(MANOVA)

ولكس لامبدا (Wilks Lambda) باسنغ م)
يتضح من جدول (2) أن معاملات الثبات لمجالات الجدية في العمل التربوي نراوحت ما لان بين (0.82 - 0.88)، وفيما يتعلق بالثبات الكلي لحني

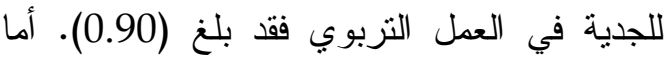
فيما يتعلق بمعامل الثبات الكلي للولاء التنظيمي لغي فقد وصل إلى (0.91)، وجميعها معاملات ثبات عالية تفي بأغر اض الدر اسة.

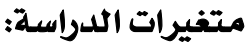
- المتغير ات المستقلة، وتتنتمل على: 1. النوع الاجتماعي، وله مستويان: ذكر ، أنثى.

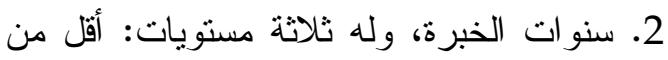
(5) سنوات، من 5-10 سنوات، أكثر من (10)

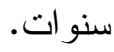

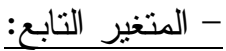




$$
\begin{aligned}
& \text { - من (70\% - 79.9\%): درجة جدية أو } \\
& \text { و لاء تتظيمي عالية. }
\end{aligned}
$$

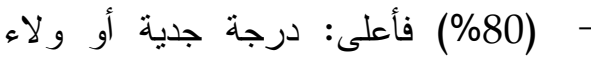

$$
\begin{aligned}
& \text { تتظيمي عالية جدَّا. }
\end{aligned}
$$

\section{أولاً: النتائج المتعلقة بالسؤال الأول:}

ما مستوى الجدية في العمل التربوي لدى معلمي المدارس الثانوية الحكومية في مديريات محافظات شمال الضفة الغربية في فلسطين؟ وهل توجد فروق ذات دلالة إحصائية عند مستوى الدلالة (a) 0.05 ) بين مجالات الجدية في العمل التربوي درول

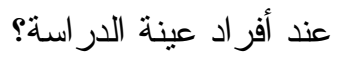
للإجابة عن الثق الأول من السؤال، استخدمت المتوسطات الحسابية، و النسب المئوية لاستجابات

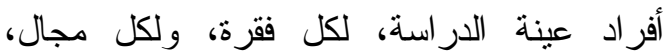
وللارجة الكلية للجدية في العمل التزبوي، ونتائج الجداول ذوات الأرقام (3، 4، 5، 6) نبين ذلك، في حين يبين جدول رقم (7) خلاصة النتائج، و الدرجة الكلية للجدية في العمل التربوي لاى لاين

$$
\text { أفر اد عينة الدر اسة. }
$$

\section{1 مجال التحدي والتغيير:}

يتضح من جدول (3) أن مستوى الجدية في العمل التربوي عند أفراد عينة الدراسة لفقرات مجال التحدي والتغيير كان عاليًا جدًا على الفقرات ذوات الأرقام (4، 13، 14)، حيث كانت النسبة المئوية للاستجابة عليها أكثر من (80\%).

واختبار سدالى Sidak Test) لتحديد الفروف بين مجالات إستبانة قياس الجدية في العمل الأكاديمي و الولاء التنظيمي. 3. تحليل التباين الثنائي ( Tow - Way (ANOVA

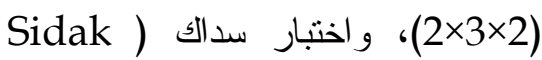
(Test المتوسطات الحسابية عند اللزوم. 4. اختبار دلالة معامل الارنباط بيرسون لتحديد (Pearson Correlation) العلاقة بين الجدية في العمل التربوي و الو لاء التتظيمي.

\section{تحليل نتائج الدراسة ومناقشتها:}

بعد جمع بيانات الدراسة، تم تحليلها وفقًا لأسئلتها

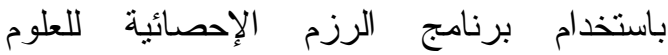
الاجتماعية (SPSS)، حيث جرى تفسير ها وفق المتوسطات الحسابية و النسب المئوية لتقدير درجة الجدية في العمل التزبوي و الولاء التتظيمي لاستجابات أفراد عينة الدراسة على سلم ليكرت

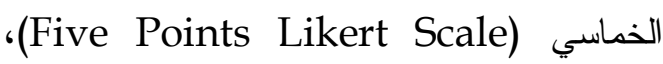
وذللك وفق الترتيب الآتي: - أقل من (50\%): درجة جدية أو ولاء

$$
\text { تتظيمي منخفضة جدًا. }
$$

- من (50\% - 59.9\%): درجة جدية أو

$$
\text { و لاء تتظيمي منخفضة. }
$$

\begin{tabular}{|c|c|c|c|c|}
\hline مستوى الجدية & المئوية \% & المتوسط & فقرات مجال التحدي و التغيير & 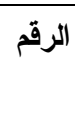 \\
\hline عال & 71.4 & 3.57 & أستنقظ و أنا جاهز للاستمر ار بالعمل الذي توققت عنده. & .1 \\
\hline عال & 77.4 & 3.87 & أر اعي التتو ع في أنثطة عملي كمعلم في المدرسة. & .2 \\
\hline متوسط & 64.6 & 3.23 & معظم الوقت بسمعني مدير المدرسة. & .3 \\
\hline
\end{tabular}

- من (60\% - 69.9\%): درجة جدية أو

و لاء تتظيمي منوسطة.

جدول رقم (3)

المتوسطات الحسابية، والنسب المئوية لمستوى الجدية في العمل التربوي لمجال التحدي والتغيير (ن = 396) 


\begin{tabular}{|c|c|c|c|c|}
\hline مستوى الجدية & النسية النوية\% & المتوسط & فقرات مجال التصدي والتغيير & 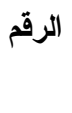 \\
\hline عالٍ جدًا & 85.0 & 4.25 & التخطيط المسبق للتدريس يساعدني على مو اجهة المشكلات المستقبلية. & .4 \\
\hline عالٍ & 73.0 & 3.65 & أستطيع كمعلم تغيير ما سوف يحدث غدًا بما أفعله اليوم. & .5 \\
\hline منخفض & 51.4 & 2.57 & إجر اء أي تغيير في برنامي اليومي يسبب لي عدم الإرنياح. & .6 \\
\hline متوسط & 69.8 & 3.49 & أتزدد كمعلم، للتقدم للوظائف حتى لو كنت جادًا في العمل. & .7 \\
\hline 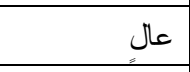 & 79.6 & 3.98 & أجد صعوبة في التفاعل مع عملي التربوي كمعلم. & .8 \\
\hline عالٍ & 73.0 & 3.65 & تعد الخبر ات العملية هي الأفضل من اجتهادي الثخصي. & .9 \\
\hline منخفض & 59.2 & 2.96 & يتم استغلال معظم المعلمين من قبل مسؤوليهم. & .10 \\
\hline منخفض & 51.0 & 2.55 & يجب تجنب وضع قو انين جديدة من شأنها أن تمس فرصة نرقية شخص ما. & .11 \\
\hline منخفض جدًا & 43.6 & 2.18 & رغم جديتي في العمل في حقل التعليم لم أسنطع تحقيق طموحاتي. & .12 \\
\hline عالٍ جدًا & 81.8 & 4.09 & أعتقد أن كل ما في الحياة مقدر أن يحدث. & .13 \\
\hline عالٍ جدًا & 85.4 & 4.27 & المعلم ذو العقلية و الفكر المستتير يمكن الاعتماد عليه لإعطاء حكم معقول. & .14 \\
\hline منخفض جدًا & 49.8 & 2.49 & أعمل بجدية في التعليم إلا أن الاعتر اف و التقدير كله يكرس للمدير. & .15 \\
\hline 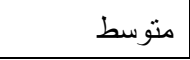 & 67.6 & 3.38 & 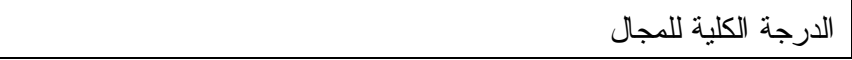 & \\
\hline
\end{tabular}

وبالنسبة للمسنوى الكلي للجدية في العمل التزبوي لمجال التحدي و التغيير فقد كان متوسطا، حيث وصلت النسبة المئوية للاستجابة إلى (67.6\%).

\section{2. مجال الالتزام والمشاركة:}

يتضح من جدول (4) أن مستوى الجدية في العمل التربوي عند أفر اد عينة الدراسة لفقرات مجال الالتز ام و المشاركة كان عالبًا جدًا على الفقر ات ذوات الأرقام (4، 5، 7، 12، 13)، حيث كانت النسبة المئوية للاستجابة عليها (80\%) فما فوق.
وكان مستوى الجدية في العمل التربوي عاليًا على الفقر ات ذوات الأرقام (1، 2، 5، 8، 9)، حيث تر اوحت نسبة الاستجابة عليها ما بين (71.4\%\%79.6\%). وفيما يتعلق بالفقر ات (6، 9، 10)، فقد

كان مستوى الاستجابة عليها منخفضًا بنسبة تتر اوح ما بين (51.0\%- 59.2\%). أما فيما يتعلق بالفقرتين (12، 15)، فقد كان مستوى الاستجابة عليهما منخفضًا جدَّا، حيث كانت النسبة المئوية للاستجابة عليهما على التو الي: (43.6\%-

.$(\% 49.8$

جدول رقم (4)

المتوسطات الحسابية، والنسب المئوية لمستوى الجدية في العمل التربوي لمجال الالتزام والمشاركة عند أفر اد عينة الدراسة

(396 = ن

\begin{tabular}{|c|c|c|c|c|}
\hline مستوى الجدية & النسبة المئوية\%\% & المتوسط & فقرات مجال الالتزام و المشاركة & الرق \\
\hline منوسط & 69.6 & 3.48 & قوله. أمتتع عن الدخول في النقاش عندما يكون الآخرون مرتبكين بما يقصدون & .1 \\
\hline منخفض جدًا & 41.8 & 2.09 & ليس مهنًّا أن أكون جديًّا في العمل لأن الأمور لا تصبح صحيحة في أي & .2 \\
\hline متوسط & 64.0 & 3.20 & الثيء المثير لاهنمامي هو أحلامي. & .3 \\
\hline عالٍ جدًًا & 86.8 & 4.34 & لا أجيب عن أي سؤال إلا بعد التأكد من فهمي له. & .4 \\
\hline
\end{tabular}




\begin{tabular}{|c|c|c|c|c|}
\hline مستوى الجدية & النسبة المئوية\% & المتوسط & فقرات مجال الالتزام و المشاركة & 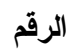 \\
\hline عالٍ جدًًا & 80.0 & 4.00 & لا أضع خططًا إلا عندما أكون متأكدًا من إمكانية تتفيذها. & .5 \\
\hline 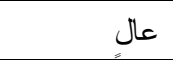 & 75.4 & 3.77 & أنثعر بأنني حقًّ أتوق للتعليم. & .6 \\
\hline 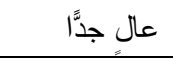 & 80.8 & 4.04 & أتضايق إذا كنت مهنمًّا بإنجاز عمل معين وطلب مني عمل شيء آخر. & .7 \\
\hline 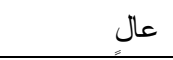 & 75.4 & 3.77 & عندما أقوم بإنجاز مهمة صعبة في المدرسة أعرف حتى أحتاج لمساعدة. & .8 \\
\hline منخفض & 59.0 & 2.95 & أجد من الصعب تغيير تفكير ور أي صديق عن شيء معين. & .9 \\
\hline 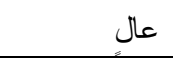 & 70.0 & 3.50 & أنزعج عندما يحدث تغيير في روتين حياتي اليومية. & .10 \\
\hline منخفض & 52.4 & 2.62 & عندما أرتكب خطأ ما هنالك شيء قليل أفعله لتصويب ذللك الخطأ. & .11 \\
\hline عالٍ جدًا & 81.6 & 4.08 & تفكيري بنفسي كثخص حر يشعرني بالتعاسة. & .12 \\
\hline عالٍ جدًا & 82.4 & 4.12 & لا حاجة للجدية في العمل لأن ذلك لن يغير في الأمور شيئًا. & .13 \\
\hline 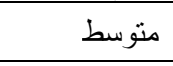 & 65.6 & 3.28 & ألتزم بالقو انين و التعليمات حتى لو تعارضت مع مبادئي و أفكاري. & .14 \\
\hline عالٍ & 70.4 & 3.52 & الدرجة الكلية للمجال & \\
\hline
\end{tabular}

التربوي لمجال الالتز ام و المشاركة فقد كان عاليًا، حيث وصلت النسبة للاستجابة إلى (70.4\%).

3. مجال السيطرة والتحكم:

يتضح من جدول (5) أن مستوى الجدية في العمل التربوي لمجال السيطرة و التحكم عند أفراد عينة الدر اسة كان عاليًا جدَّا على الفقرات ذورات الأرقام

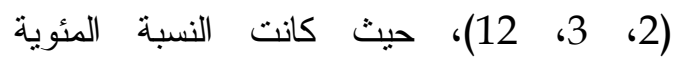
للاستجابة عليها أكثر من (80\%).
وكان مسنوى الجدية في العمل التربوي عاليًا على الفقرات ذوات الأرقام (6، 8، 10)، في حين كان مستوى الاستجابة على الفقرنين (9، 11) منخفضًا بعد أن وصلت النسبة المئوية للاستجابة عليهما (259.0\%- 52.4\%) على التو الي، و الفقرة (25) كان مستوى الاستجابة عليها منخفضًا جدًا، حيث وصلت النسبة للاستجابة عليها إلى (41.8\%). وفيما يتعلق بالمستوى الكلي للجدية في العمل

جدول رقم (5) جأ (5)

المتوسطات الحسابية، والنسب المئوية لمستوى الجدية في العمل التربوي لمجال السيطرة والتحكم عند أفراد عينة الدراسة

$(396=0)$

\begin{tabular}{|c|c|c|c|c|}
\hline مستوى الجدية & النسبة المئوية\%\% & المتوسط & فقرات مجال السيطرة و التحكم & 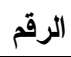 \\
\hline عالٍ & 78.0 & 3.90 & أحد طرق علاج المشكلات هو إهمالها. & .1 \\
\hline عالٍ جدًَّا & 81.2 & 4.06 & أفضل الأشياء التي تكون جادة. & .2 \\
\hline عالٍ جدًًا & 83.2 & 4.16 & يجب إعطاء دعم مادي كامل من المجتمع للأشخاص ذوي الجدية في العمل. & .3 \\
\hline عالٍ & 76.6 & 3.98 & معظم الوقت لا أعرف حقيقة أفكاري. & .4 \\
\hline منخفض & 53.0 & 2.65 & النظريات غير الواقعية لا تثير اهتمامي. & .5 \\
\hline منخفض & 51.8 & 2.59 & العمل العادي ممل جدًا بالنسبة إليّ & .6 \\
\hline عال & 73.4 & 3.67 & يغضب الناس مني حتى لو كان الأمر لأسباب بسيطة. & .7 \\
\hline 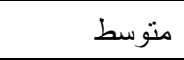 & 65.4 & 3.27 & يصعب تصديق الأشخاص الذين يقولون أن العمل الذين يقومون به مفيد للمجتمع. & .8 \\
\hline عالٍ & 75.6 & 3.78 & إذا حاول أحد إيذائي لا يمكنتي عمل شيء لمنعه عن ذلك. & .9 \\
\hline منخفض & 54.4 & 2.72 & أعتقد أن الناس يؤمنون بالحياة لجذب نظر الآخرين. & .10 \\
\hline منخفض & 58.2 & 2.91 & أشعر أن معظم أيام الحياة غير ممتعة لي. & .11 \\
\hline عالٍ جدًا & 81.8 & 4.14 & أحاسب نفسي إذا قصرت في عملي التربوي في المدرسة. & .12 \\
\hline
\end{tabular}




\begin{tabular}{|c|c|c|c|c|}
\hline 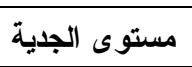 & 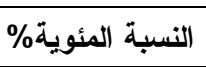 & 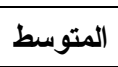 & فقرات مجال السيطرة و التحكم & الرقم \\
\hline منخفض جدًَا & 44.8 & 2.24 & معظم أيام حياتي تمضي في عمل وجد و هذا العمل لا يحوي نوعاً من الفائدة. & .13 \\
\hline 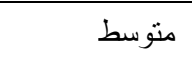 & 67.8 & 3.39 & 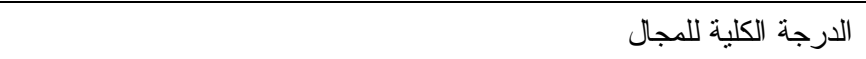 & \\
\hline
\end{tabular}

"قأقصى درجة للاستجابة (5) درجات.

4. ترتيب المجالات، والدرجة الكلية لمستوى الجدية يِّ العمل التربوي:

يتضح من جدول (6) أن مستوى الجدية في العمل التربوي عند أفراد عينة الدراسة كان متوسطاً،

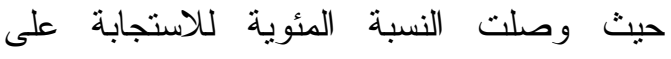
الدرجة الكلية إلى (68.6\%). وفيما يتعلق بترنيب

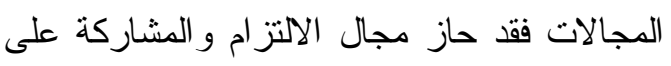
المرنبة الأولى، وبنسبة استجابة بلغت (70.4\%)، في حين حاز مجال السيطرة و التحكم على المرنبة الثانية، حيث وصلت النسبة المئوية للاستجابة إلى ولى (67.8\%). أما مجال التحدي و التغيير فقد حاز على المرنبة الثالثة و الأخيرة (67.6\%)، ونظهر هذه النتيجة بوضوح في الثكل البياني رقم (1).
وكان مستوى الجدية في العمل التربوي عاليًا على الفقرات (1، 4، 7، 8)، حيث نراوحت النسبة المئوية للاستجابة عليها ما بين (73.4\%\%79.6). أما الفقر ات التي كان مستوى الاستجابة عليها منخفضًا فتمنلت بالفقرات (5، 6، 10، 10، 11)، حيث تراوحت النسبة المئوية للاستجابة عليها ما بين (51.8\%- 58.2\%)، وبالنسبة للفقرة رقم (13) فقد كان مستوى الاستجابة عليها منخفضًا جدًا، حيث وصلت النسبة المئوية للاستجابة عليها إلى (44.8\%). وفيما يتعلق بالمستوى الكلي للجدية في العمل التربوي لمجال

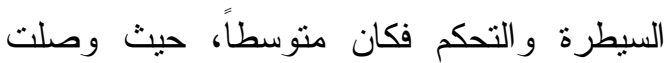
النسبة المئوية للاستجابة إلى (67.8\%).

جدول رقم (6) - جالوب

الترتيب و المتوسطات الحسابية، والنسب المئوية لمجالات الجدية في العمل التربوي وللارجة الكلية لمستوى الجدية في العمل

التربوي لاى أفر اد عينة الدراسة (ن =396)

\begin{tabular}{|c|c|c|c|c|}
\hline مستوى الجدية & النسبة المئوية \% & منوسط الاستجابة & المجالات & التزتيب \\
\hline متوسط & 67.6 & 3.38 & مجال التحدي و التغيير & 3 \\
\hline عال & 70.4 & 3.52 & مجال الالتز ام و المشاركة & 1 \\
\hline منوسط & 67.8 & 3.39 & مجال السيطرة و التحكم & 2 \\
\hline متوسط & 68.6 & 3.43 & \multicolumn{2}{|c|}{ لدرجة الكلية للجدية } \\
\hline
\end{tabular}




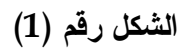

المتوسطات الحسابية لمجالات الجدية في العمل التربوي عند معلمي المدارس الثانوية في مديريات محافظات شمال الضفة الغربية في فلسطين

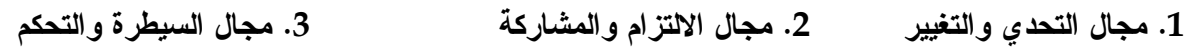

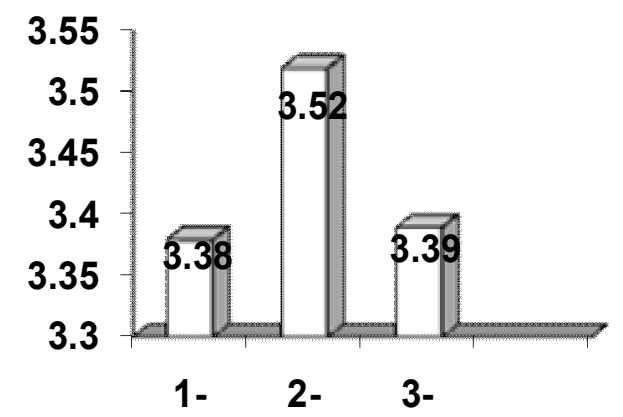

شخصية وبيئية مدرسية غير سوية أثرت سلبيًّا وكما تشير معطيات نتائج جدول (6)، يرى على قدرة المعلم وجديته نحو العمل و العطاء. الباحث أن السبب في تدني مستوى الجدية العام وفيما يتعلق باستجابات أفر اد عينة الدراسة على (68.6\%) عن المستوى المرغوب، قد يعود إلى لـ كل مجال من مجالات الجدية في العمل التزبوي، ارتفاع مستوى التذمر عند المعلمين من الجو لوحظ أن مجال الالتزام و المشاركة احتل المرتبة التعليمي العام في المدارس، بسبب عدم انتظام الأولى (70.4\%)، وتتفق هذه النتيجة مع دراسة الطلبة بالدوام المدرسي وضعف التحصيل

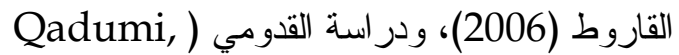
الدراسي في أوساط الطلبة، وكذلك انتتار ظاهرة 2001)، بحصول مجال الالتز ام و المشاركة على المرتبة الأولى بالنسبة للمجالات الأخرى، ويرى العنف في المدارس نتيجة غياب سلطة النظام و القانون في مناطق السلطة الوطنية الفلسطينية، الباحث أن هذا الأمر قد يعود إلى التزام المعلم التي مزقت حواجز جيش الاحتلال أوصالها، الفلسطيني في بيئة العمل، و اندماجه فيه، خدمة للعملية التزبوية ولأهداف وتنطلعات المجتمع الفلسطيني للتخلص من الاحتلال، ونيل الحرية

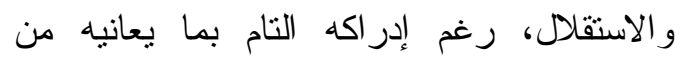

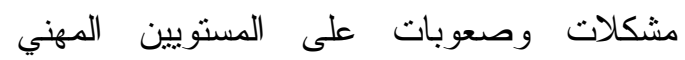
و الثخصي، ورغم إدر اكه بما يعانيه المجتمع من ولن

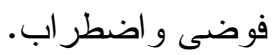
أما بالنسبة لحصول مجالي السيطرة و التحكم،

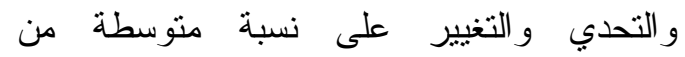
الاستجابة (67.8\%- 67.6\%) على التو الي، فهذا يعود إلى أن كلا المجالين يرتبطان مباشرة ببيئة وتعرضت مختلف مدنها و وقراها ومخيماتها للعمليات العسكرية و المداهمات المستمرة. فجميع هذه الأسباب انعكست سلبًا على دافعية المعلمين وجديتهم نحو العملية التعليمية في المدارس التي ينتمون إليها. وتتفق هذه النتيجة في مضمونها مع

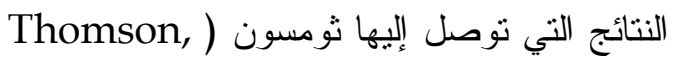
1995) في دراسته، و التي أظهرت أن المعلمين الذين كانوا في مستوى غير مرغوب دراب من الجدية في العمل التربوي، هم بالتأكيد في مستوى عالٍ من النفور من المناخ المدرسي، فالدراسة أظهرت علاقة إيجابية بين الجدية في العمل كخاصية 
ويتتاسب مع مستوى الحياة الاجتماعية الكريمة التي ينشدها، سيجعله أكثر رضا وحيوية، وأكثر اطمئناناً على نفسه و أسرته، كما ويجعله أكثر انتماء وجدية و اندماجًا في عمله، وبالمقابل فإن حدوث أبي خلل يمس هذا الو اقع، سيؤدي حتمًا إلى التأثنير سلبًا على جهده و عطائه، لأنه يشتت تفكيره في البحث عن بدائل تعيد الطمائنينة إلى نفسه

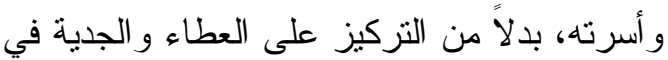

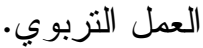
وفيما يتعلق بأفضل مستويات الاستجابة نحو الجدية في العمل التربوي في المجالات المختلفة، تتير نتائج جدول (3) المتعلق بمجال التحدي و التغيير أن أعلى مستويات الاستجابة كان للفقرة رقم (14) المتضمنة "المعلم ذو العقلية و الفكر المستتير يمكن الاعتماد عليه لإعطاء حكم معقول" (85.4\%)، و الفقرة رقم (4) المنضمنة "التخطيط المسبق للتنريس يساعدني في مو اجهة المشكلات المستقلية" (85\%)، و الفقرة رقم (13) المنضمنة

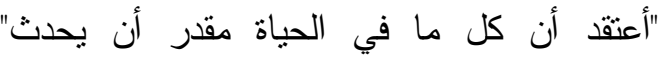
(81.8\%)، ومن خلال النظر إلى منل هذه الاستجابات يتضح أنها ترنبط مباشرة بشخصية إلها

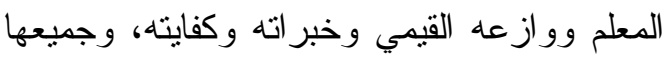

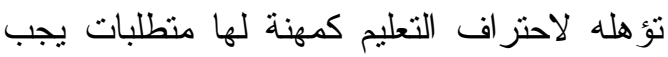
أن تتوافر فيمن يرغب فيها، ومن أهمها العقلية

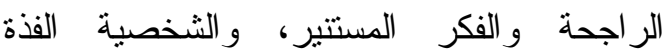

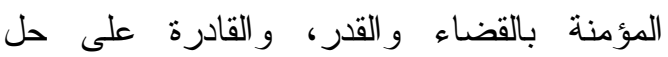

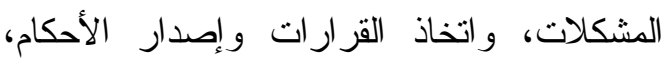
إضافة إلى القدرة على التخطيط الواعي و السليم لعناصر التربية وجوانبها المتعددة. وتتفق هذه النتيجة مع ما توصل إليه الثرعة و الباكر

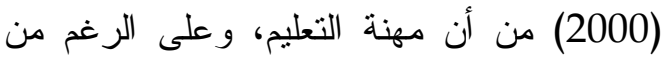
أنها تقع في المستوى الأدنى من الكادر الوظيفي للوظائف الحكومية، إلا أن المعلم يتمتع بأفق و اسع لهن لهن
العمل، ويشكلان تحديًا لقدرات المعلم في السيطرة و التحكم و التغيير، وأن العمل بموجبهما ينطلب

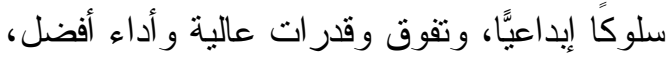
كما يتطلب إحداث تغييرات جذرية في بيئة العمل (المدرسة)، كما يحتاج إلى تخطيط مبني ومدروس لأحداث التغيير المطلوب بالجوهر، وليس فقط بالشكل و المظهر، وخلاصة القول، فإن إحداث التغيير المرغوب يتطلب مستوى عاليًا من المعرفة

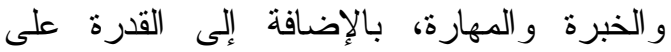
التواصل و الاتصال، كما يتطلب مهارات تتخيصية متخصصة للتعرف على أماكن الخلل لعلاجها بما يحقق الأهداف ويرضي الطموحات. وحيث إن المدرسة كمؤسسة رسمية تخضع للقو انين و الأنظمة المدرسية النابعة لوزارة التزبية والتعليم العالي، فإن منح المعلمين الحرية في التغيير و النطوير تنقى محدودة، إن لم تكن بعيدة المنال، وذلك نظرًا لالتز امهم التام بتعليمات أنظمة الرقابة الإدارية المعمول بها في المدارس، بالإضافة إلى نظام الإثر اف المباشر عليهم من قبل المديرين و المشرفين التزبويين، مما يحد من الطن إمكانية إحداث التغيير المطلوب في المدارس. إن هذا هو واقع الحال الذي ينطبق على النظام التعليمي الفلسطيني في الظروف الطبيعية، فكيف يمكن تصور الوضع التزبوي العام في المدارس في أجو اء يسودها الفوضى و العنف، وتتفشى فيها

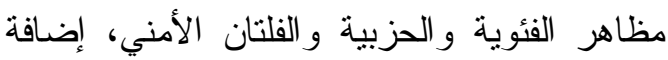
إلى ما أحدثه انقطاع الرواتب عن المعلمين لعدة ولهيه

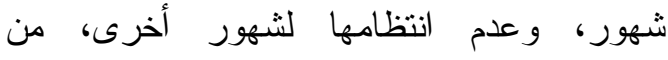
مصاعب اقتصادية ومعيشية على المعلمين و أسر هم؟ وتتفق هذه النتيجة في مجملها مع النتيجة التي توصل إليها القاروط (2006) بأن حصول المعلم على راتب يكافئ عمله ويلبي حاجاته

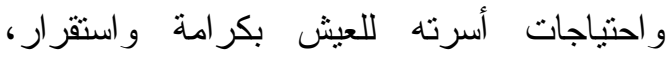


تتمنل بعو امل العزيمة القوية والإرادة الصادقة،

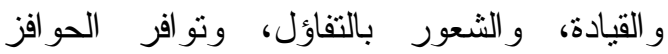
و الجو ائز للمجدين في عملهم، و الاحتز ام و التقدير

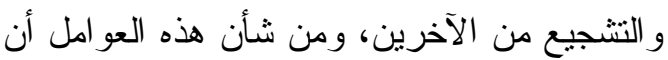
تسهم في تطوير بنية الإنتاج، لأنها خلقت حالات هن التهن

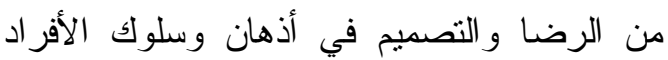
العاملين نحو العمل و الإنتاج. وفيما يتعلق بمجال السيطرة والتحكم، أظهرت نتائج جدول رقم (5) أن أعلى مستويات الجدية

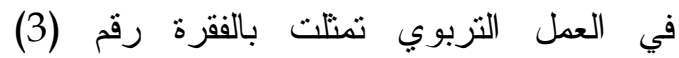
المتضمنة "يجب إعطاء دعم مادي كامل من

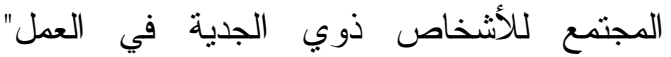
(83.2\%)، و الفقرة رقم (12) المتضمنة "أحاسب نفسي إذا قصرت في عملي التربوي في المدرسة" وهاب (81.8\%)، و الفقرة رقم (2) "أفضل الأشياء التي فئري تكون جادة" (81.2\%). ومن خلد النظر إلى منل هذه الفقرات تتضح درجة التمني التي بطمح المعلم لبلوغها، و التي تتمثل بضرورة دعم المعلمين الجادين و المخلصين في عمهم، معنويَّا وماديًا، إيمانًا منه بأنه هو الثخص وله المسؤول

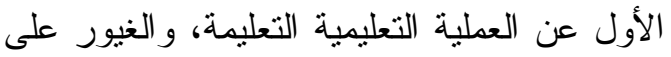

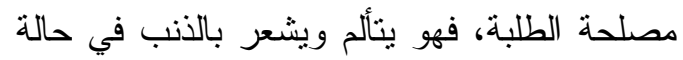

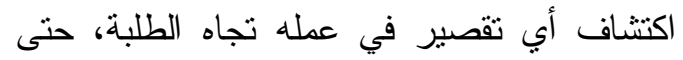

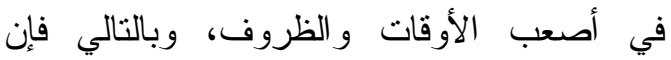
المعلم يشعر بالفخر و الاعتزاز بمهنته، ويتمنى دائمًا أن يعطي أفضل ما عنده من خبرة وعلم،

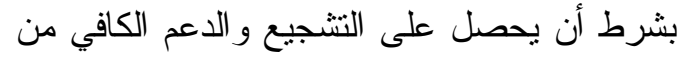

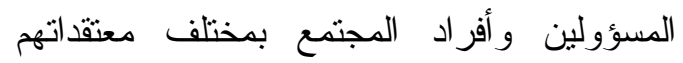

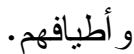

وتتفق هذه النتيجة في مضمونها مع النتائج التي

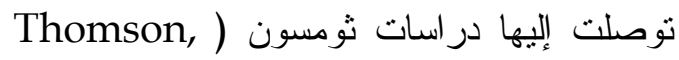
1995)، وسومتش وبوكر ( Somech \&

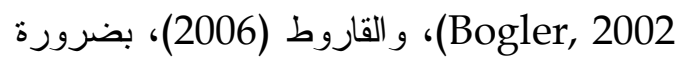

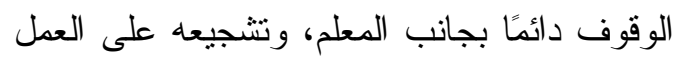

في تحدي الحاضر من أجل تغييره لرسم المستقبل

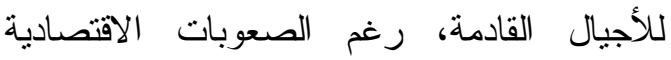
والاجتماعية و النفسية التي يو اجهها في حياته المهنية، بشرط أن تتو افر الظروف المشجعة على لئى لئه ذلك. أما فيما بتعلق بمجال الالتز ام و المشاركة، أظهرت نتائج جدول رقم (4) أن أعلى مستويات الجدية في العمل التربوي تمنلت بالفقرة رقم (4) المتضمنة "لا أجيب عن أي سؤال إلا بعد التأكد من فهمي له" (86.8\%)، و الفقرة رقم (13) المتضمنة "لا حاجة للجدية في العمل لأن ذلك لن يغير في الأمور شيئًا" (82.4\%)، و الفقرة رقم لانه

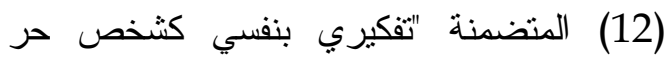
يشعرني بالتعاسة" (81.6\%)، و الفقرة رقم (7)

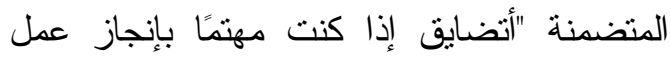
معين وطلب مني عمل شيء آخر" (80.8\%)، و الفقرة رقم (5) المنضمنة "لا أضع خططًا إلاء ألاء عندما أكون متأكدًا من إمكانية تتفيذها" (80\%). ومن خلال تفحص مثل هذه الفقرات يلاحظ حالة

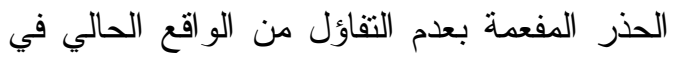
وجدان المعلمين، لأن الجاد وغير الجاد في عمله،

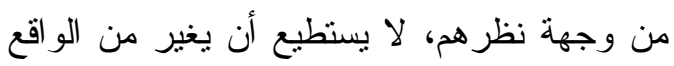

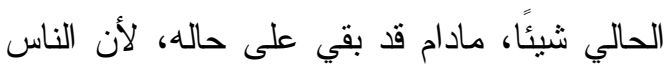
أنفسهم ليس لديهم القدرة على التغيير في منل هذه لنها الظروف الصعبة من الزمن، وفي ظل انعدام

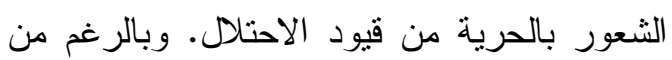

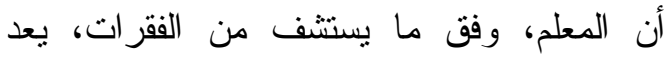
الأكثر تفهمًا من غيره إلى ما وصلت إليه قيم

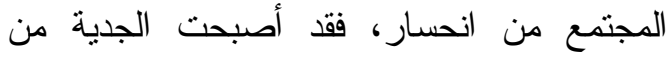

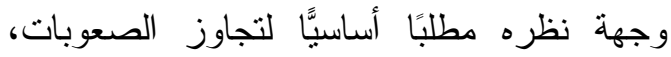
بشرط أن تتو افر العزيمة و الإر ادة الصادقة لتحقيق ذللك. وفي السياق ذاته يؤكد الموسوي (2004) في حديثه عن إدارة الموارد البشرية، أن من أهم العو امل التي تسهم في اندفاع الفرد للعمل و الإنتاج 
الجدية في العمل التربوي، فقد تم استخدام تحليل التباين متعدد المتغير ات التابعة (MANOVA) وذللك باستخدام الاختبار الإحصائي ولكس لامبدا (Wilk's Lambda) تبين ذلك.

والإنتاج، والأخذ بيده لضمان تحقيق الأهداف،

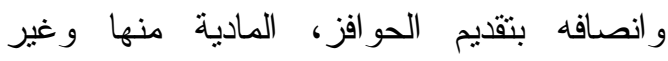
المادية، تقديرًا لجهوده المخلصة في التزبية

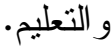
أما فيما يتعلق بالإجابة عن الثق الثاني من السؤال الأول المتعلق بتحديد الفروق بين مجالاتهن

جدول رقم (7)

نتائج اختبار ولكس لامبدا لدلالة الفروق بين مجالات الجدية في العمل التربوي

\begin{tabular}{|r|r|r|r|r|}
\hline قيمة ولكس لامبدا & 0.879 \\
\hline
\end{tabular}

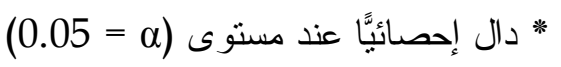

يتضح من جدول رقم (7) أنه توجد فروق ذات دلالة إحصائية عند مستوى (a = 0.05) بين مجالات الجدية في العمل التربوي عند معلمي المدارس الثانوية الحكومية في مديريات محافظات شمال الضفة الغربية في فلسطين. ولتحديد بين أي من المجالات كانت الفروق، استخدم اختبار سداك (Sidak Test) للمقارنات الثنائية بين المتوسطات الحسابية، ونتائج جدول رقم (8) نبين ذلك.

جدول رقم (8)

نتائج اختبار سدالك لالالة الفروق بين مجالات الجدية في العمل التربوي

\begin{tabular}{|c|c|c|c|c|c|}
\hline 3 & 2 & 1 & المتوسط & المجالات & الرقم \\
\hline-0.003 & $*-0.132$ & & 3.38 & التحدي و التغيير & .1 \\
\hline \multirow[t]{2}{*}{$* 0.129$} & & & 3.52 & الالتز ام و المشار كة & .2 \\
\hline & & & 3.39 & السبطرة و التحكم & .3 \\
\hline
\end{tabular}

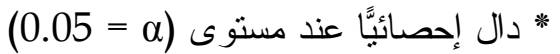

سلوكهم نحو الالتزام في بيئة العمل، و الميل الإيجابي إلى المشاركة بالعمل التربوي والاندماج بنشاطاته المختلفة بفاعلية و اقتدار، و اضعين بنظر الاعتبار قدرتهم عل تحديد أهدافهم و إدر الك قيمهم

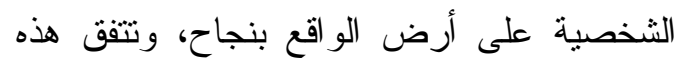

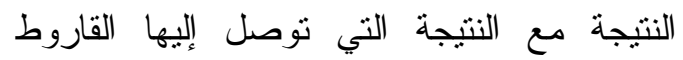
(2006) بأن حصول مجال الالنزام و المشاركة على المرتبة الأولى من وجهة نظر أفراد عينة

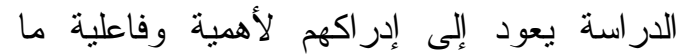
يقومون باه عن طريق دمج أنفسهم في بيئة عملهم ليه

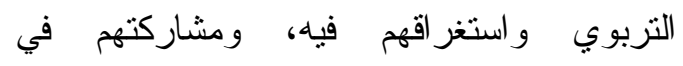

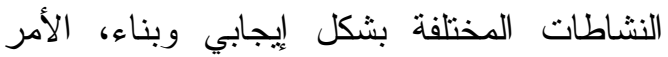

يتضح من جدول (10) أنه نوجد فروق ذات دلالة

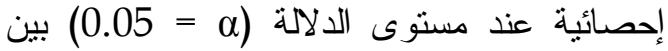
مجالات الجدية في العمل التربوي عند معلمي المدارس الثانوية الحكومية في مديريات محافظات شمال الضفة الغربية في فلسطين، حيث كانت الفروق دلالة إحصائَّا بين مجالي التعدي و التغيير ومجال الالتز ام و المشاركة ولصالح مجال الالتز ام و المشاركة، وبين مجال الالتزام و المشاركة و السيطرة والتحكم ولصالح مجال الالتز ام و المشاركة، ويرى الباحث أن السبب في ذلك يعود إلى أن مجال الالتزام و المشاركة يعد من وجهة نظر المعلمين من أكثر المجالات الجدية تأثثرًا في 
للإجابة عن السؤال، استخدمت المتوسطات الحسابية، و النسب المئوية لاستجابات أفراد عينة

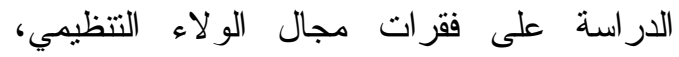
و النتائج في جدول رقم (9) تبين ذلك.
الذي ينعكس إيجابًا على المدرسة ومناخها، ورفع سمعة المدرسة و إظهار نشاطاتها. ثانياً: النتائج المتعلقة بالسؤال الثاني:

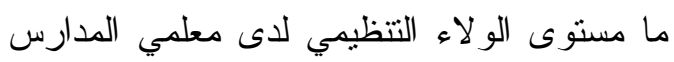
الثانوية الحكومية في مديريات محافظات شمال الضفة الغربية في فلسطين؟

\section{جدول رقم (9) - (9)}

المتوسطات الحسابية، والنسب المئوية لمستوى الولاء التظظيمي لاى معلمي المدارس الثانوية الحكومية في مديريات محافظات شمال الضفة الغربية في فلسطين (ن = 396)

\begin{tabular}{|c|c|c|c|c|}
\hline مستوى & المئوية & المتوسط & فقرات مجال الولاء التنظيمي & الرقم \\
\hline عال & 76.4 & 3.82 & تمنل الددرسة جزءًا هامًّا من حياتي ومن الصعب ابتعادي عنها. & .1 \\
\hline عالٍ جدًا & 84.0 & 4.20 & أعامل أولياء الأمور بكياسة تجلب السمعة الحسنة للمدرسة. & .2 \\
\hline 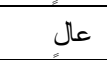 & 72.8 & 3.64 & أفضل مصلحة المدرسة على مصلحتي الثخصية. & .3 \\
\hline عالٍ جدًا & 90.2 & 4.51 & أثني على الطالب المجتهذ و أشجعه على تحقيق الإنجاز ات العلمية. & .4 \\
\hline عالٍ جدًا & 80.6 & 4.03 & أؤمن بأن التدريس مهنة تخضع للأنظمة و القو انين و العمل المؤسسي. & .5 \\
\hline عالٍ جدًا & 84.0 & 4.20 & أعمم الأفكار الجديدة على التلاميذ للاستفادة منها على أرض الواقع. & .6 \\
\hline 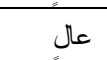 & 78.2 & 3.91 & أثنجع إثنر الك المعلمين في الدور ات و الندو ات لاكتساب الخبر ات المتعلقة بالمهنة وصقلها. & .7 \\
\hline عالٍ جدًا & 89.8 & 4.49 & أحافظ على ممتلكات المدرسة كمحافظتي على ممنلكاتي الثخصية. & .8 \\
\hline 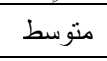 & 62.2 & 3.11 & أتجنب استخدام العو اطف في التعامل مع الآخرين في المدرسة. & .9 \\
\hline عالٍ & 74.2 & 3.71 & يقيم المعلم على أساس قدرته على تحقيق الأهداف. & .10 \\
\hline عالٍ جدًا & 82.8 & 4.14 & لاي الاستعداد لبذل جهد أكبر لإنجاح عمل المدرسة التي أعمل فيها. & .11 \\
\hline عالٍ & 77.6 & 3.88 & أميل إلى الاستعانة بخبر اء المجتمع لإثراء العملية التربوية في المدرسة. & .12 \\
\hline عالٍ جدًا & 87.2 & 4.36 & يهمني جدًا تفوق الطلاب في المدرسة التي أعمل فيها. & .13 \\
\hline 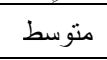 & 61.4 & 3.07 & لا أمانع من التأخر في المدرسة إذا اقتضت الضرورة ذلك. & .14 \\
\hline 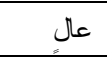 & 76.0 & 3.80 & أتحسس المشكلات التي تو اجه المدرسة و أقدم المقترحات البناءة لتذليلها. & .15 \\
\hline 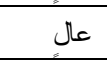 & 73.4 & 3.67 & أثعر بثقارب شديد بين أهدافي وأهداف المدرسة التي أعمل فيها. & .16 \\
\hline 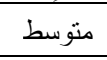 & 64.0 & 3.20 & أرفض ترك عملي إذا تلقيت عرضًا أفضل من ر انتي في المدرسة. & .17 \\
\hline منخفض & 51.8 & 2.59 & أثنعر بالرضا عن عملي لأن ما أتقاضاه من ر اتبي يرضي طموحاتي. & .18 \\
\hline 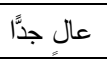 & 80.4 & 4.02 & أؤمن بأن اهتمام الإدارة بالمعلمين يزيد من جهدهم و عطائهم نحو المدرسة. & .19 \\
\hline 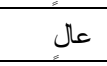 & 78.2 & 3.91 & أثنعر بأن لي تأثيرًا في المجتمع بسبب عملي معلمًا في المدرسة. & .20 \\
\hline عالٍ جدًا & 81.4 & 4.07 & أثنعر بر غبة كييرة في العطاء كوني أعمل معلمًا في المدرسة. & .21 \\
\hline 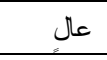 & 79.0 & 3.95 & أعتقد أنني اسنطعت تحقيق أثنياء مهمة لمجتمعي كوني أعمل معلمًا. & .22 \\
\hline عالٍ جدًا & 80.2 & 4.01 & أنشعر بالراحة و الطمأنينة عندما أعمل مع زملائي في المدرسة. & .23 \\
\hline عالٍ جدًا & 82.4 & 4.12 & أثنعر بالاعتزاز بمهنتي في تربية وتعليم النشء في المدرسة. & .24 \\
\hline عالٍ جدًا & 86.2 & 4.31 & سعادتي تتجلى في تقديم يد العون لزملاتئي في المدرسة. & .25 \\
\hline عالٍ جدًا & 89.6 & 4.48 & أتضايق كثيرًا من تقشي ظاهرة العنف في أوساط الطلبة في المدرسة. & .26 \\
\hline عالٍ جدًا & 82.8 & 4.14 & أثنعر بأنني أمتلك القدرة على إيجاد أجو اء نفسية مريحة مع زملائي في المدرسة. & .27 \\
\hline عالٍ جدًا & 84.8 & 4.24 & أتأثنر كثيرًا بما تعانيه الطالبات من مضايقات في محيط المدرسة. & .28 \\
\hline عالٍ & 78.2 & 3.91 & \multicolumn{2}{|c|}{ ل الدرجة الكلية للمجال } \\
\hline
\end{tabular}

"أقصى درجة للاستجابة (5) درجات. 
الجديدة على التلاميذ للاستفادة منها على أرض الرض الواقع (84\%)، ولدي الاستعداد لبذل جهد أكبر

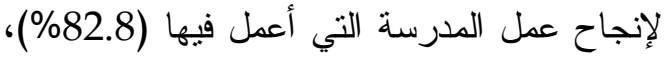
و أثنعر بأنني أمتلك القدرة على إيجاد أجواء نفسية مريحة مع زملائي في المدرسة (82.8\%). ومن خلال تفحص منل هذه الفقرات يتضح مستوى الولاء الرفيع الذي يتمتع به معلمو المدرسة الثانوية في فلسطين نحو عمهم التربوي، والذي ينم عن الثقدير والاحتر ام لهذه النخبة المتميزة من كو ادر الثعب الفلسطيني، التي كانت وما زالت تتمسك بقيمها وو اجبها المقد تجاه مجتمعها في التربية و التعليم، ومد يد العون والمساعدة لهما، على الرغم من المحن و الصعاب التي تو اجهها، و التي كان للاحتلال البغيض النصيب الأكبر في لوني إيجادها. وبناء على ما سبق ذكره، يعزو الباحث السبب الذي يكمن وراء ارتقاء مستوى الولاء النتظيمي عند معلمي المدارس الثانوية، إلى وعيهم التام بأهمية الدور القيادي الذي يقومون به في بناء

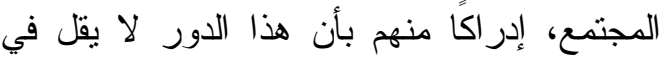
أهيته عن النضال الذي يقوم به بقية أفراد اد الدان المجتمع الفلسطيني في مقاومة جيش الاحتلال.

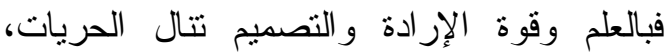

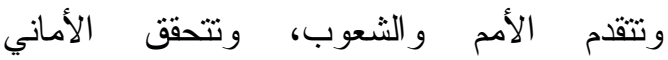

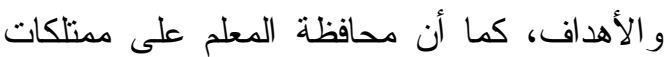
المدرسة، وبناء علاقات جيدة مع الزملاء و الطلبة و الأهالي، وتقديم يد العون و المساعدة لهم، يندرج أيضًا في إطار مستوى الو لاء الراقي الذي يتمتع به المعلم في هذا المجال، وتتقق هذه النتيجة في مضمونها مع النتائج التي توصلت إليها دراسات Somech ( إير اهيم (1996)، وسومتش وبوكلر إن 2002 \& Bogler, 2002 وغنام (2005)، وقد أثشارت إلى أن المعلم الناجح هو المعلم الذي يتسم بالتقة بنفسه، وبقدر اته، ويتمتع بالمهارة و اللباقة
يتضح من جدول (5) أن مستوى الو لاء التتظيمي عند معلمي المدارس الثانوية الحكومية في لوني مديريات محافظات شمال الضفة الغربية في فلسطين كان عاليًا جدًا على الفقرات ذوات الأرقام (2) 4، 5، 6، 8، 11، 13، 19، 24، 23، 25، 26، 27، 28)، حيث وصلت النسبة المئوية للاستجابة عليها أكثر من (80\%). وكان مستوى الو لاء التنظيمي عاليًا على الفقرات (1، 3، 7، 10، 12، 15، 16، 20، 22) حيث نزاوحت النسبة المئوية للاستجابة عليها ما بين (72.8\% \%79.0\%). وفيما ينعلق بالفقرات (9، 4، 17)، فقد كان مستوى الاستجابة عليها منوسطا، إذ نر اوحت النسبة المئوية للاستجابة عليها ما بين (61.4\%64.0\%). وكان مستوى الو لاء التتظيمي منخفضًا على الفقرة رقم (18)، حيث وصلت النسبة المئوية للاستجابة عليها إلى (51.8\%).

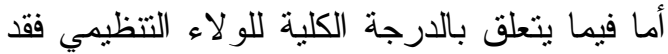

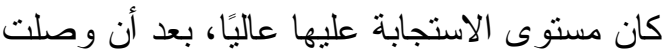
النسبة المئوية للاستجابة إلى (78.2\%). وكما تشير معطيات نتائج جدول (5)، فقد تمنلت أعلى مستويات الو لاء التنظيمي وفق نرتيب نسبها

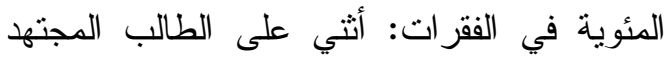
و أثنعه على تحقيق الإنجازات العلمية (90.2\%)، وأحافظ على ممنلكات المدرسة

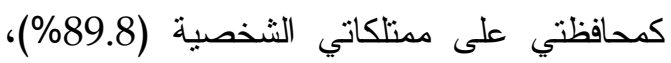
وأتضايق كثيرًا من تفتي ظاهرة العنف في أوساط الطلبة في المدرسة (89.6\%)، ويهمني جدًا تفوق الطلبة في المدرسة الني أعمل فيها (87.2\%)، وسعادتي تتجلى في تقديم بد العون

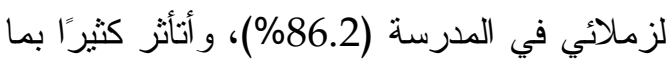
تعانيه الطالبات من مضايقات في محيط المدرسة (84.8\%)، وأعامل أولياء الأمور بكياسة تجلب السمعة الحسنة للمدرسة (84\%)، و أعمم الأفكار 
مستوى الاضطراب الذي يعاني منه المعلم من جر اء عدم كفاية الراتب الذي يتقاضاه في عمله

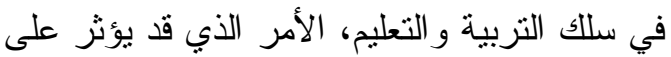
مستوى الو لاء لليه، ومن خلال النظر إلى منل هذه الفقرة، تتضح درجة المعاناة التي يعاني منها المعلم من جر اء عدم كفاية الراتب، و الذي انعكس سلبًا على تحقيق طموحاته للعيش بكفاية، و القيام بو اجباته المطلوبة نحو أسرته ومدرسته ومجتمعه. وتعزز هذه النتيجة مع ما توصل إليه الباحث في هذه الدراسة بأن حدوث أي خلل يمس راتب ماتب المعلم، سيؤدي حتمًا إلى التأثير سلبًا على جهده و عطائه نحو عمله، لأنه يشتت تفكيره بالتركيز على عمله، ويجبره على البحث عن بدائل تعيد

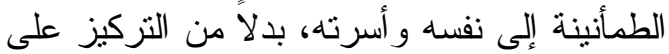
العطاء و الجدية في العمل. ثالثاً: النتائج المتعلقة بالسؤال الثالث: هل هنالك علاقة ارتباطية ذات دلالة إحصائية عند مستوى الدلالة ( = 0.05) بين الجدية في العمل التزبوي و الولاء التنظيمي عند معلمي المدارس الثنانوية الحكومية في مديريات محافظات شمال الضفة الغربية في فلسطين؟ للإجابة عن هذا السؤال، استخدم اختبار معامل ارتباط بيرسون (Pearson Corr) وجدول رقم (10) يبين ذلك.

في التعامل مع الآخرين، و القدرة على الضبط وحسن التصرف، و إدارة المواقف التعليمية و الاجتماعية، وجميعها تكسب المعلم احترام من

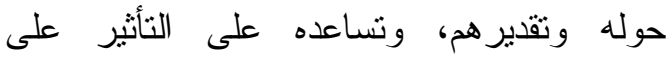
الآخرين، ونوصيل المعلومة بكل يسر وسهولة.

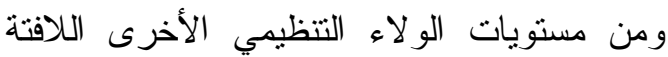

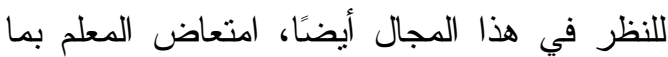
يحدث في المدارس من فوضى وعنف، ومضايقات في محيط بعض المدارس، مما يعطل

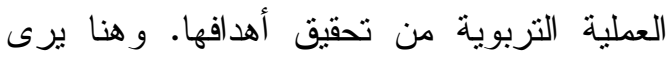
الباحث أن ما يحدث في المجتمع من عنف لفن وفوضى وسلبيات، سبزول أثزه حال عودة النظام و القانون إلى مناطق السلطة الوطنية، إيماناً منه بأصالة هذا الثعب، وبقدرته على تجاوز الصعاب بعلاج هذه الظاهرة الدخيلة على عادات شعبنا وتقاليده، ووعيه بأن دماء الثهداء التي سالت غزيرة على نزاب هذا الوطن لن تذهب هدرًا، وبالتالي يمكن القول: إنه بهمة المخلصين من أمثال المعلمين، و الغيورين على مصلحة هذا الوطن ستزول قرييًا كل أسباب و آثار السلبيات التي علقت بجسد هذا الثعب الصابر و المناضل. وفي المقابل، فإن شعور المعلم بعدم الرضا عن الر اتب، كما أثنارت إليه الفقرة (18) و المتضمنة "أشعر بالرضا عن عملي لأن ما أنقاضاه من راتب يرضي طموحاتي" (51.8\%)، بدل على دئ

جدول رقم (10) - (10)

نتائج اختبار معامل الارتباط بيرسون للعلاقة بين الجدية في العمل التربوي والولاء التظظيمي عذد معلمي المدارس الثانوية الحكومية في مديريات محافظات شمال الضفة الغربية في فلسطين

\begin{tabular}{|c|c|c|c|c|c|}
\hline \multirow[t]{2}{*}{ مستوى الدلالة } & \multirow[t]{2}{*}{ (১) } & \multicolumn{2}{|c|}{ الو لاء التنظيمي } & \multicolumn{2}{|c|}{ الجدية في العمل } \\
\hline & & الانحر اف & الهنوسط & الانحر اف & الكتوسط \\
\hline$* 0.0001$ & 0.53 & 0.48 & 3.91 & 0.19 & 3.43 \\
\hline
\end{tabular}

* دال إحصائياً عند مستوى (a)

في مديريات محافظات شمال الضفة الغربية في فلسطين، حيث بلغت قيمة معامل ارتباط بيرسون
يتضح من جدول (10) أن العلاقة إيجابية ودلالة النة إحصائيًا بين الجدية في العمل التربوي و الولاء التنظيمي عند معلمي المدارس الثانوية الحكومية 
الضفة الغربية تعزى للتغير النوع الاجتماعي وسنوات الخبرة و التفاعل بينهما؟ للإجابة عن السؤال استخدم تحليل النباين الثنائي بأحد صوره العاملية (2×3×2)، حيث تبين نتائج جدولين (11 و 12) المتوسطات الحسابية، ونتائج تحليل التباين الثنائي لمجالات الجدية في العمل

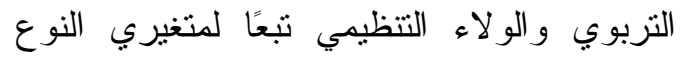
الاجتماعي وسنوات الخبرة لدى أفراء ادئ عينة

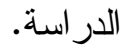

جدول رقم (11)

المتوسطات الحسابية لمجالات الجدية في العل التربوي و الولاء التنظيمي عند أفراد عينة الدراسة تبعًا لمتغيري النوع الاجتماعي وسنوات الخبرة

\begin{tabular}{|c|c|c|c|c|c|}
\hline المتوسط الموزون & سنورات من (10) & من5-10سنوات & سنو ات من (5) & النوع الاجتماعيم الخبرة & والولاء التنظيمي الجدية في العل \\
\hline 3.46 & 3.43 & 3.56 & 3.36 & ذكر & \multirow{3}{*}{ التحدي والتغيير } \\
\hline 3.33 & 3.37 & 3.36 & 3.28 & أثنى & \\
\hline 3.39 & 3.40 & 3.46 & 3.32 & المتوسط الموزون & \\
\hline 3.44 & 3.58 & 3.22 & 3.37 & ذكر & \multirow{3}{*}{ الالتز ام والمشاركة } \\
\hline 3.56 & 3.60 & 3.55 & 3.54 & أنثى & \\
\hline 3.47 & 3.59 & 3.38 & 3.45 & المتوسط الموزون & \\
\hline 3.44 & 3.45 & 3.37 & 3.55 & ذكر & \multirow{3}{*}{ السيطرة و التحكم } \\
\hline 3.36 & 3.37 & 3.53 & 3.22 & أنثى & \\
\hline 3.40 & 3.41 & 3.45 & 3.38 & المتوسط الموزون & \\
\hline 3.45 & 3.49 & 3.39 & 3.43 & ذكر & \multirow{3}{*}{ مستوى الجدية الكلي } \\
\hline 3.42 & 3.44 & 3.48 & 3.34 & أنثى & \\
\hline 3.42 & 3.46 & 3.43 & 3.38 & المتوسط الموزون & \\
\hline 3.87 & 3.48 & 4.02 & 3.61 & ذكر & \multirow{3}{*}{ مستوى الولاء التنظيمي } \\
\hline 3.94 & 4.04 & 4.03 & 3.74 & أنثى & \\
\hline 3.78 & 3.67 & 4.02 & 3.67 & المتوسط الموزون & \\
\hline
\end{tabular}




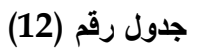

نتائج تحليل التباين الثائي لالالة الفروق في الجدية في العمل التربوي والولاء التنظيمي و الارجة الكلية عند أفراد عينة الدراسة

تبعًا لمتغيري النوع الاجتماعي وسنوات الخبرة و التفاعل بينهما

\begin{tabular}{|c|c|c|c|c|c|c|}
\hline الدلالة مستوى & 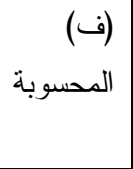 & الانحر اف & مربعوع الاتحر افات & 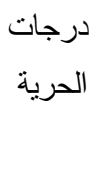 & مصدر التباين & مجالات الجدية في العمل \\
\hline$* 0.001$ & 11.91 & 1.036 & 1.036 & 1 & النوع & \multirow[t]{5}{*}{ التحدي و التغيير } \\
\hline *0.012 & 4.49 & 0.391 & 0.782 & 2 & الخبرة & \\
\hline \multirow[t]{3}{*}{0.35} & 2.01 & 0.175 & 0.350 & 2 & النوع×الخبرة & \\
\hline & & 0.087 & 33.928 & 390 & الخطأ & \\
\hline & & & 36.674 & 395 & المجموع & \\
\hline *0.0001 & 42.73 & 2.160 & 2.160 & 1 & النوع & \multirow[t]{5}{*}{ الالتز ام و الششاركة } \\
\hline *0.0001 & 28.27 & 1.429 & 2.585 & 2 & الخبرة & \\
\hline \multirow[t]{3}{*}{ *0.0001 } & 16.83 & 0.851 & 1.702 & 2 & النوع×الخبرة & \\
\hline & & 0.050 & 19.712 & 390 & الخطأ & \\
\hline & & & 25.408 & 395 & المجموع & \\
\hline *0.016 & 5.84 & 0.526 & 0.526 & 1 & النوع & \multirow[t]{5}{*}{ السيطرة و التحكم } \\
\hline 0.272 & 1.30 & 0.118 & 0.235 & 2 & الخبرة & \\
\hline \multirow[t]{3}{*}{ *0.0001 } & 14.16 & 1.275 & 2.551 & 2 & النوع×الخبرة & \\
\hline & & 0.090 & 35.121 & 390 & الخطأ & \\
\hline & & & 39.732 & 395 & المجموع & \\
\hline 0.630 & 0.23 & 0.008 & 0.008 & 1 & النوع & \multirow{5}{*}{ الثربوية الكلية للجدية في العمل } \\
\hline${ }^{*} 0.017$ & 4.13 & 0.148 & 0.296 & 2 & الخبرة & \\
\hline \multirow[t]{3}{*}{ *0.003 } & 6.05 & 0.216 & 0.433 & 2 & النوع×الخبرة & \\
\hline & & 0.035 & 13.938 & 390 & الخطأ & \\
\hline & & & 15.079 & 395 & المجموع & \\
\hline$* 0.041$ & 4.21 & 0.933 & 0.933 & 1 & النوع & \multirow[t]{5}{*}{ الدرجة الكلية للو لاء التنظيمي } \\
\hline$* 0.001$ & 11.76 & 2.604 & 5.207 & 2 & 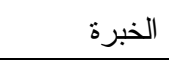 & \\
\hline \multirow[t]{3}{*}{0.241} & 1.39 & 0.310 & 0.619 & 2 & النوع×الخبرة & \\
\hline & & 0.221 & 86.319 & 390 & الخطأ & \\
\hline & & & 74.220 & 395 & المجموع & \\
\hline
\end{tabular}

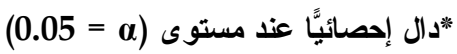

يتضح من جدول رقم (11) أن هنالك فارقًا من ذلك أظهرت نتائج تحليل التباين الثنائي في و واضحًا بين المتوسطات الحسابية في مجالات

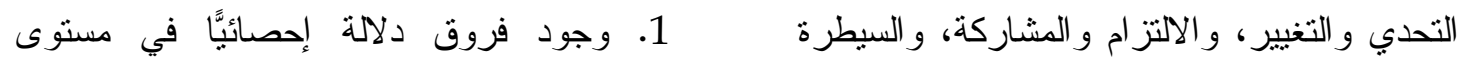
الجدية في العمل النزبوي عند أفراد عينة

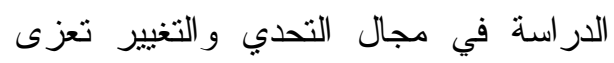

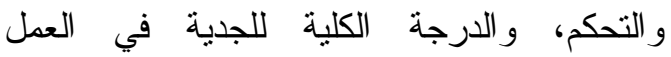

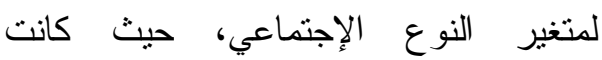
التربوي، و الدرجة الكلية للولاء التظظيمي تبعًا

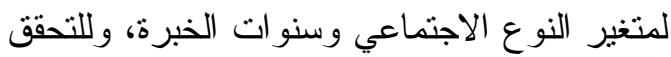


مستويات سنوات الخبرة كانت الفروق، استخدم اختبار سداك (Sidak Test) للمقارنات البعدية بين المتوسطات الحسابية، ونتائج جدول (12) تبين ذلك.

6. وجود تفاعل بين متغير النوع الاجتماعي ومتغير سنوات الخبرة في مجال الالتزام و المشاركة، حيث كانت قيمة (ف) المحسوبة تساوي (16.83)، وهي قيمة دلالة إحصائيًا

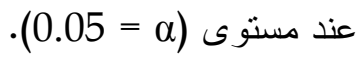
7. وجود فروق دلالة إحصائيًا في مجال

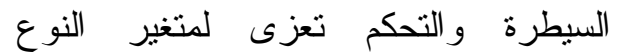
الاجتماعي، حيث كانت قيمة (ف) المحسوبة تساوي (5.84)، و هي قيمة دلالة إحصائيًا

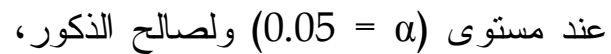
حيث كان متوسطهم (3.44) مقابل فئة الإناث ومتوسطها (3.36). 8. لا توجد فروق ذات دلالة إحصائية في مجال السبطرة و التحكم تعزى لمتغير سنوات الخبرة، حيث كانت قيمة (ف) المحسوبة تساوي (1.30)، وهي قيمة ليست دلالة إحصائيًا عند مستوى ( $\alpha$ = 0.05). 9. وجود تفاعل بين متغيري النوع الاجتماعي لوني

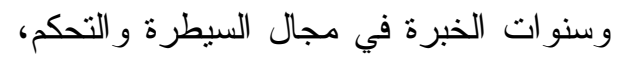
حيث كانت قيمة (ف) المحسوبة تساوي

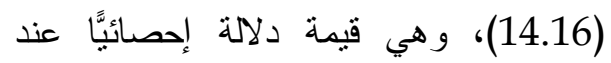

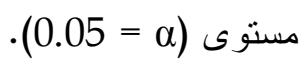

10. لا توجد فروق ذات دلالة إحصائية في مجال الدرجة الكلية للجدية في العمل التربوي تعزى لمتغير النوع الاجتماعي، حيث كانت قيمة (ف) المحسوبة تساوي (0.23)، وهي ليمي

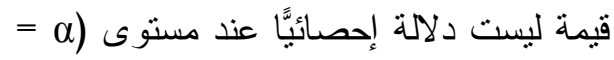
. $(0.05$
قيمة(ف) الهحسوبة تساوي (11.91)، وهي قيمة دلالة إحصائيًا عند مسنوى (a) 0.05) ولصالح الذكور ، حيث كان متوسطهم

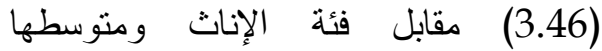

2. وجود فروق ذات دلالة إحصائية في مستوى الجدية في العمل التربوي عند أفراد عينة الدراسة في مجال التحدي والتغيير تعزى لمتغير سنوات الخبرة، حيث كانت قيمة (ف) المحسوبة تساوي (4.49)، وهي قيمة دلالة

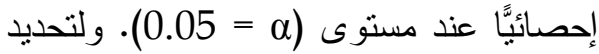
بين أيِّ مستويات سنوات الخبرة في مجال التحدي و التغيير كانت الفروق، استخدم Sidak Popst-Hoc-) اختبار سدائ Test الحسابية، ونتائج جدول (12) تبين ذلك. 3. لا يوجد تفاعل بين متغير النوع الاجتماعي ومتغير سنوات الخبرة في مجال التحدي و التغيير، حيث كانت قيمة (ف) المحسوبة فئرة تساوي (2.01)، وهي قيمة غير دلائلة إحصائًّا عند مستوى (a = 0.05). 4. وجود فروق دلالة إحصائيًا في مجال الالتز ام

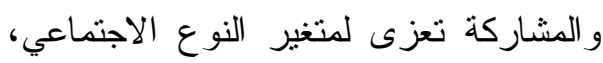
حيث كانت قيمة (ف) المحسوبة نساوي

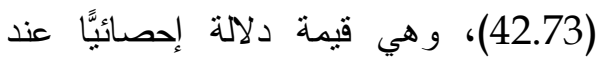

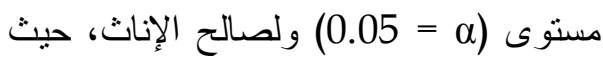

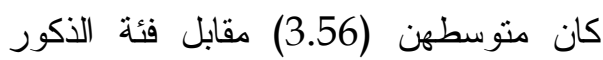
ومنوسطها (3.44). 5. وجود فروق ذات دلالة إحصائية في مجال الالتزام و المشاركة تعزى لمتغير سنو لته الخبرة، حيث كانت قيمة (ف) المحسوبة ولة تساوي (28.27)، وهي قيمة دلالة إحصائيًا

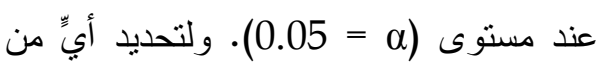


سنوات الخبرة، حيث كانت قيمة (ف) (1) المحسوبة تساوي (11.76)، و هي قيمة دلالة

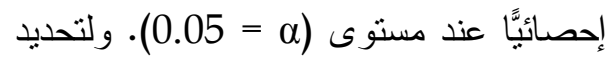
أيٍٍ من مستويات سنوات الخبرة كانت

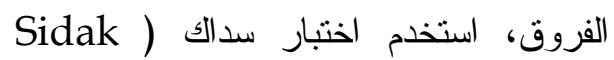
(Test الحسابية، ونتائج جدول (12) تبين ذلك.

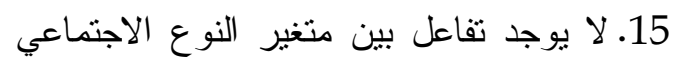
ومتغير سنوات الخبرة في مجال الدرجة

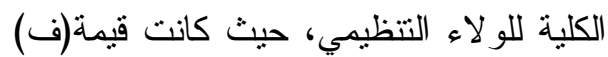
المحسوبة تساوي (1.39)، وهي قيمة غير

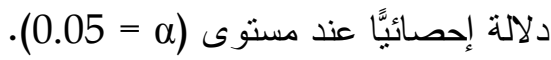
وكما نشير معطبات نتائج جدول (11) حول الفروق في مستوى الجدية في العمل الثربوي و الولاء التتظيمي عند أفراد عينة الدراسة تبعًا للنوع الاجتماعي، يتضح أن الذكور بشكل عام لاء

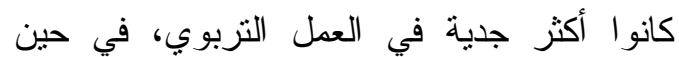

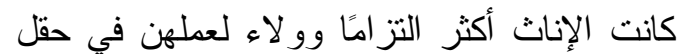
التزبية و التعليم من الذكور • وفي ضوء هذه النتيجة يعتقد الباحث أن هذه النتيجة جاءت منطقية وتتفق تمامًا مع العرف التربوي بأن الإناث غالبًا ما يثبتن جدارتهن و اهتمامهن و التزامهن بعملهن

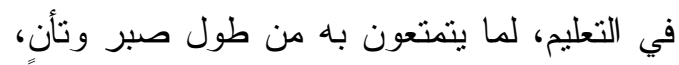

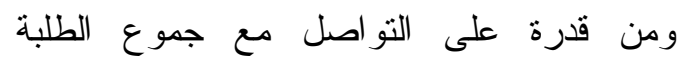
لمساعدتهم في تحصبلهم العلمي أكثر من الذكور .
11.وجود فروق ذات دلالة إحصائية في مجال الدرجة الكلية للجدية في العمل التربوي تعزى لمتغير سنوات الخبرة، حيث كانت قيمة (ف) المحسوبة نساوي (4.13)، وهي

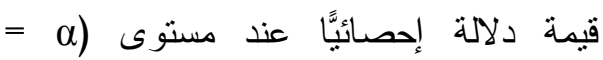

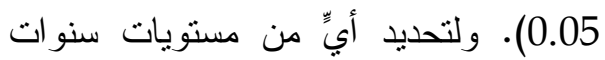
الخبرة كانت الفروق، استخدم اختبار سداك الك للمقارنات البعدية بين (Sidak Test) الكتوسطات الحسابية، ونتائج جدول (12) تنين ذلك. 12.وجود تفاعل بين متغير النوع الاجتماعي ومتغير سنوات الخبرة في مجال الدرجة الكلية للجدية في العمل التربوي، حيث كانت قيمة (ف) المحسوبة تساوي (6.05)، وهي

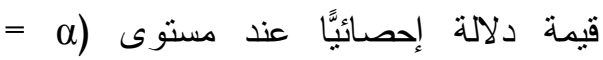
. (0.05 13.وجود فروق دلالة إحصائيًا في مجال الدرجة الكلية للولاء التتظيمي تعزى لمتغير النوع الاجتماعي، حيث كانت قيمة (ف) المحسوبة تساوي (4.21)، وهي قيمة دلالة إحصائيًا

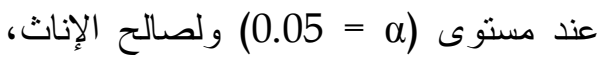
حيث كان منوسطهن (3.94) مقابل فئة الذكور ومتوسطها (3.87). 14.وجود فروق ذات دلالة إحصائية في مجال الدرجة الكلية للو لاء التنظيمي تعزى لمتغير

جدول رقم (13) - جل فين نتائج اختبار سداك (Sidak Test) لدلالة الفروق في مستوى الجدية في العمل التربوي والو لاءالتظيمي لاى معلمي المدارس الثانوية الحكومية في محافظات شمال فلسطين تبعًا لمتغير سنوات الخبرة

\begin{tabular}{|c|c|c|c|c|c|}
\hline أكثر من & سنوات-10 سنو & سنقل من (5) & المتوسط & سنوات الخبرة & \\
\hline 0.077 & $*-0.138$ & & 3.32 & أقل من (5) سنو ات & \multirow[t]{3}{*}{ مجال التحدي و التغيير } \\
\hline \multirow[t]{2}{*}{0.061} & & & 3.46 & من5-10 سنو ات & \\
\hline & & & 3.40 & أكثر من (10) سنو ات & \\
\hline$*-0.135$ & 0.063 & & 3.45 & أقل من (5) سنو ات & \multirow[t]{2}{*}{ ججال الالتز ام و المشاركة } \\
\hline$*-0.198$ & & & 3.39 & من5-10 سنو ات & \\
\hline
\end{tabular}




\begin{tabular}{|c|c|c|c|c|c|}
\hline أكثر من & سنو5-10 منوات & سنول من (5) & المتوسط & سنوات الخبرة & \\
\hline & & & 3.59 & أكثر من (10) سنوات & \\
\hline-0.021 & -0.069 & & 3.38 & أقل من (5) سنو ات & \multirow[t]{3}{*}{ مجال السيطرة و التحكم } \\
\hline \multirow[t]{2}{*}{0.047} & & & 3.45 & من5-10 سنو ات & \\
\hline & & & 3.41 & أكثر من (10) سنو ات & \\
\hline$*-0.077$ & -0.047 & & 3.39 & أقل من (5) سنو ات & \multirow{3}{*}{ الدرجة الكلية لمجالات } \\
\hline \multirow[t]{2}{*}{-0.029} & & & 3.43 & من5-10 سنو ات & \\
\hline & & & 3.46 & أكثر من (10) سنو ات & \\
\hline$*-0.269$ & $*-0.352$ & & 3.68 & أقل من (5) سنو ات & \multirow{3}{*}{ الدرجة الكلية لمجال الو لاء } \\
\hline \multirow[t]{2}{*}{-0.083} & & & 3.03 & من5-10 سنو ات & \\
\hline & & & 3.94 & أكثر من (10) سنو ات & \\
\hline
\end{tabular}

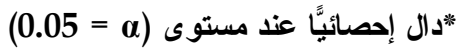

ولصالح أصحاب سنوات الخبرة (أكثر من 10 سنوات)، في حين لم تكن الدقارنات البعدية الأخرى دلالة إحصائيًا. وتعني مثل فئ فئل

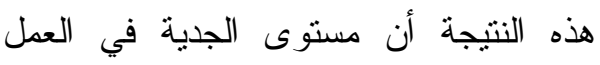

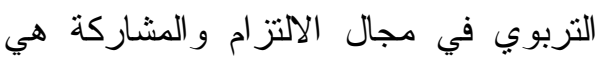
أفضل عند أصحاب سنوات الخبرة الطويلة،

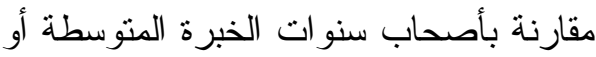
القصيرة. 3. لا نوجد فروق دلالة إحصائيًا عند مستوى

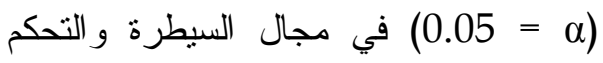
تعزى للتغير سنوات الخبرة في مختلف

$$
\text { المستويات. }
$$

4. أن الفروق كانت دلالة إحصائيًا عند مستوى

4) الجدية في العمل التربوي بين أصحاب سنو ات الخبرة (أقل من 5 سنو ات) و وأصحاب العن سنوات الخبرة (أكثر من 10 سنوات اتل ولصالح أصحاب سنوات الخبرة (أكثر من 10 سنوات)، في حين لم تكن المقارنات البعدية الأخرى دلالة إحصائيًا. وتعني متل التهات هذه النتيجة أن الدرجة الكلية لمجالات الجدية
يضضح من جدول (13) ما يلي: 1. أن الفروق كانت دلالة إحصائيًا عند مستوى (13 الفي ( 1 = 0.05 في مجال التحدي و التغيير بين أصحاب سنوات الخبرة (أقل من 5 سنوات) وأصحاب سنوات الخبرة (من 5-10) سنوات ولصالح أصحاب سنوات الخبرة (من 5-10) سنوات، في حين لم تكن المقارنات

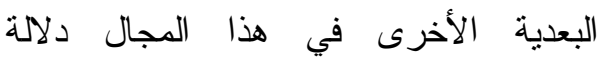
إحصائًاً. وتعني متل هذه النتيجة أن مستوى الجدية في العمل التربوي في مجال التحدي والتغيير هي أفضل عند أصحاب سنوات التئل الخبرة (من 5-10 سنوات) من أصحاب سنوات الخبرة القصيرة. 2. أن الفروق كانت دلالة إحصائيًا عند مستوى لكئر 2) بين أصحاب سنوات الخبرة (أقل من 5 سنوات) وأصحاب الخبرة (أكثر من 10 سنوات) ولصالح أصحاب سنوات الخبرة (أكثز من 10 سنوات)، وبين أصحاب سنوات الخبرة (من5-10 سنوات) و أصحاب سنوات الخبرة (أكثر من 10 سنوات) 
و التزامات ومسؤوليات في مضمار العمل، من تخطيط ومتابعة وتتفيذ وتقويم، سو اء على صعيد

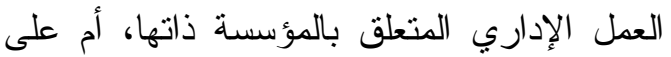
صعيد العمل التربوي المتعلق بالطلبة أنفسهم،

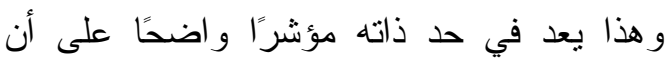
هناك علاقة إيجابية بين الخبرة و الجدية في العمل، وبالتالي، يمكن القول بأن نز اكم الخبرة العملية عند المعلمين يؤدي إلى الارنقاء بمستوى الجدية لديهم في العمل التزبوي، وتتفق هذه النتيجة في مضمونها مع النتيجة التي توصل إليها القدومي (Qadwmi, 2001)، والتي أظهرت وجود التهات فروق ذات دلالة إحصائية في مجالات الجدية في ولي

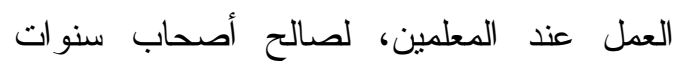

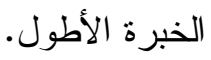
أما في ضوء مقارنة نتائج جدولين (12 و 13) حول الفروق في مستوى الجدية في العمل هنول التربوي و الو لاء التتظيمي عند أفر اد عينة الدراسة تبعًا لمتغيري النوع الاجتماعي وسنوات الخبرة للمعلمين و التفاعل بينهما، فقد تبين من نتائج تحليل التباين الثنائي في جدول (12)، ونتائج اختبار سيداك للمقارنات البعدية بين المتوسطات الحسابية في جدول (13) ما يلي:

\section{فيما يتعلق بمجال التحدي والتغيير، أظهرت} النتائج أن الذكور الذين يتمتعون بسنوات خبرة مال بين (5-10 سنوات) هم أكثر جدية وولاء في العمل التزبوي من زملائهم وزميلاتهم الإناث

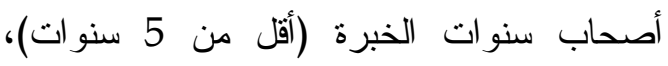
ويرى الباحث أن السبب في ذللك قد يعود إلى أن هذه الفئة أكثر جرأة ومغامرة من غيرهاب هاب من الفئات، كما قد يعود الأمر إلى تمتع هذه الفئة

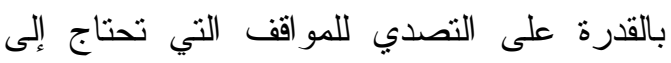
تغيير بما تمليه المواقف و الظروف المستجدة، وهي الفئة الثابة و المفعمة بالحيوية و النشاط
في العمل التربوي هي أفضل عند أصحاب سنو ات الخبرة الطويلة، مقارنة بأصحاب سنو ات الخبرة المتوسطة أو القصيرة.

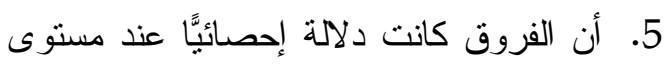
(الدي التتظيمي بين أصحاب سنوات الخبرة (أقل من 5 سنو ات) و أصحاب سنو ات الخبرة (من 5-10 سنوات) ولصالح أصحاب سنوات وات سنوات الخبرة (من 5-10 سنوات)، وبين أصحاب

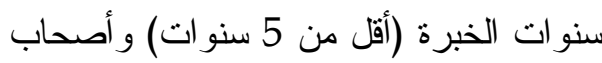
سنوات الخبرة (أكثر من 10 سنوات) ولصالح أصحاب سنوات الخبرة (أكثر من 10 سنوات)، في حين لم تكن المقارنات

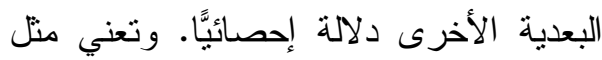
هذه النتيجة أن الدرجة الكلية في مجال الولاء التتظيمي هي أفضل عند أصحاب سنوات الخبرة الطويلة، مقارنة بأصحاب سنوات الخبرة المتوسطة أو القصبرة. وفي ضوء عرض نتائج جدول (13) حول نتائج اختبار سدالك لدلالة الفروق في مستوى الجدية في العمل التربوي و الولاء التنظيمي عند أفراد عينة الدراسة تبعًا لسنوات الخبرة، يتبين أن الذين يتمتعون منهم بسنوات خبرة أطول هم أكثر الفئات

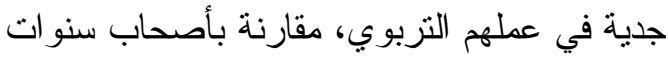
الخبرة المنوسطة أو القصبرة، وفي كل المجالات

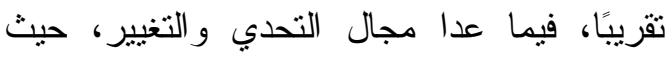
وصفت الجدية و الولاء عند أصحاب سنوات الخبرة (من 5-10 سنوات) بالأعلى، مقارنة بزملائهم أصحاب سنوات الخبرة (أقل من 5 سنوات). ويمكن تفسير هذه النتيجة من خلال الثقدير بأن سنوات الخبرة الطويلة عادة ما تمنح صاحبها القدرة الأكبر في التعامل مع منطلبات العمل بجدية من زملائه أصحاب سنوات الخبرة الأدنى، وما يندرج في إطار ها من و واجبات 
أما فيما يتعلق بمجال السيطرة والتحكم، فقد أظهرت النتائج أن الذكور، بغض النظر عن سنوات خبراتهم، كانو ا أكثر قدرة على السيطرة و التحكم وتحمل المسؤولية في مضمار العمل، و أكثز قدرة على تحمل أعباء العمل من الإناث، حيث وصفت الجدية في العمل التربوي لديهم في هذا المجال بالأعلى، مقارنة بالإناث ذوات سنوات الخبرة المختلفة، وبالتالي يمكن القول، بأن الطبيعة الذكرية عادة ما تفرض نفسها على الأنثى بالرغبة

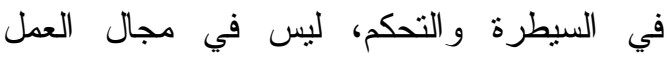

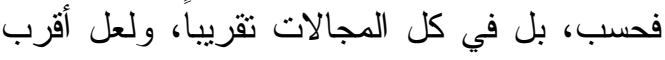
مثال على ذلك ما يحدث في مجتمعاتنا الثرقية ولية

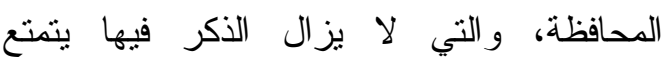
بالحظوة والاهتمام من قبل ذويه أكثر من الأنثى،

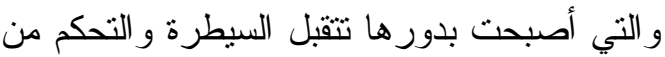
قبل الرجل عليها في مختلف مجالات الحياة تقريبًا.

وبناء على ما سبق ذكره يمكن القول، إن مستوى

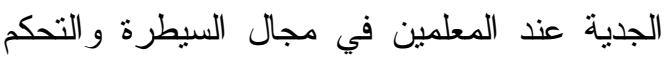
كان الأعلى مما هو عند المعلمات، وتتفق هذه النتيجة مع النتيجة التي توصلت إليها دراسة ولتهات القدومي (Qadumi, 2001)، و التي أظهرت وجود فروق ذات دلالة إحصائية في مجالات

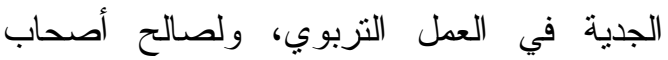
سنو ات الخبرة الطويلة من المعلمين. وفيما يتعلق بمستوى الجدية في العمل التزبوي

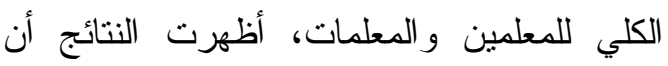
الجدية في العمل التربوي كانت لصالح أصحاب سنو ات الخبرة الطويلة، سواء من الذكور كانو أم أم المبل الإناث، و هذا تأكيد على ما ذكره الباحث سابقًا بأن أصحاب سنوات الخبرة الطويلة هم أكثر جدية في
و التسرع في بعض الأحيان، وعليه فلا غرابة أن تتمتع هذه الفئة بالقدرة على المجازفة والتحدي للواقع أكثر من غيرها من فئات سنوات الخبرة الأخرى، سواء كانو ا ذكورًا أم إناثًا، وذللك نظرًا لامتلاكها لبعض الخبرات التي تؤهلها للقيام بما لتها

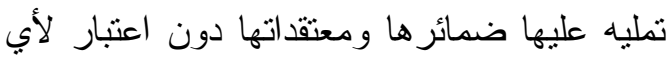
توجهات أخرى. وتتفق هذه النتيجة مع النتيجة التي توصل إليها القدومي (Qadumi, 2001) بأن الفئة الثابة من المعلمين، التي تحظى بسنوات خبرة متوسطة في الإدارة و التدريس، كانت الأقدر من غيرها على التحدي للظروف، بل الأقدر على التأقلم مع كل ما ميطر أ عليها من مستجدات

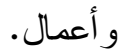

\section{وفيما يتعلق بمجال الالتزام والمشاركة، بينت}

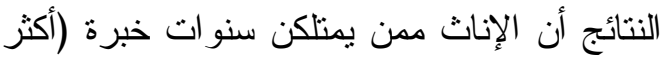
من 10 سنوات) كن أكثز جدية في العمل التزبوي من زملائهن وزميلاتهن في فئات سنوات الخبرة الأخرى، ويرى الباحث أن السبب في ذلك قد يعود إلى أن المعلمات بطبيعتهن بملن إلى الاتز ام بالعمل بجدية أكثر من المعلمين، بل المشاركة بمختلف النشاطات و الفعاليات الاجتماعية و التربوية، وبالتالي يمكن القول، إن طول سنوات الخبرة عند المعلمات أكسبهن القدرة الأكبر على الالتز ام بمنطلبات العمل المشاركة فيه بجدية وفاعلية ومثابرة، الأمر الذي ينسجم مع طبيعتهن

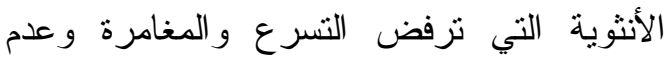
المبالاة، وتختلف هذه النتيجة عمّا توصل إليها القاروط (2005) بأنه لا توجد فروق ذات دلالة إحصائية في مجال الالنزام و المشاركة تبعاً لمتغيري النوع الاجتماعي وسنوات الخبرة. 


\section{| الاستنتاجات: - ال}

في ضوء عرض نتائج الدر اسة ومناقتنتها بسنتتج

$$
\text { الباحث ما يلي: }
$$

1. وجود مستوى جدية منوسط في العمل عند

معلمي المدارس الثانوية الحكومية في في

مديريات محافظات شمال الضفة الغربية في

فلسطين، حيث وصلت النسبة المئوية

للاستجابات على مجالات الجدية في العمل

التربوي الكلية إلى (68.6\%).

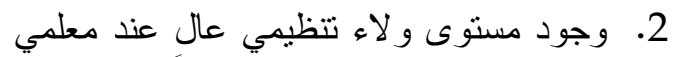

المدارس الثانوية، حيث وصلت النسبة

المئوية للاستجابة على مجال الو لاء التظظيمي

الكلي إلى (78.2\%).

3. إن أعلى مستوى للجدية في العمل التربوي

عند أفراد عينة الدراسة كان في مجال الالتز ام و المشاركة (70.4\%)، وكان أقل فئ

مستوى من الجدية في العمل التربوي في ولاني

$$
\text { مجال التحدي و التغيير (67.6\%). }
$$

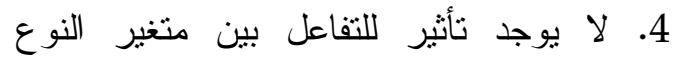

الاجتماعي وسنو ات الخبرة في مجال التحدي لاعير

و التغيير؛ ومتغير سنوات الخبرة في مجال

السيطرة و التحكم؛ ومتغير النوع الاجنماعي وني

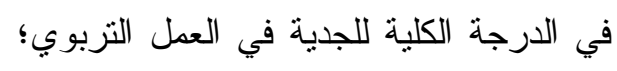

و التفاعل بين متغيري النوع الاجتماعي

وسنوات الخبرة في مجال الدرجة الكلية

للو لاء التتظيمي.

5. يوجد تأثثر لمتغيري النوع الاجتماعي

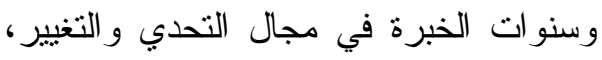

لصالح الذكور من أصحاب سنوات الخبرة

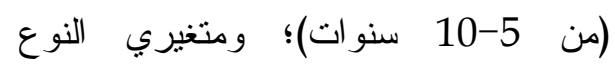

الاجتماعي وسنوات الخبرة، والتفاعل بينهما

في مجال الالتزام و المشاركة ولصالح

المعلمات ذوات سنوات الخبرة الطويلة؛

ومتغير النوع الاجتماعي و التفاعل بين
العمل من أصحاب سنوات الخبرة المتوسطة أو

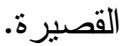

أما فيما يتعلق بالمستوى الكلي للولاء التنظيمي

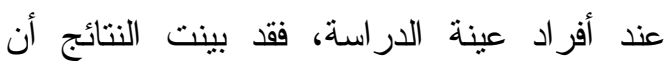
المعلمات ذو ات سنو ات الخبرة المتوسطة و الطويلة كن أكثر و لاء من زميلاتهن ذوات سنوات الخبرة القصبرة، وكذلك كن أكثر و لاء و التزامًا بعملهن من زملائهن المعلمين في مختلف فئات سنوات الخبرة، ويرى الباحث أن السبب في هذه النتيجة قد يعود إلى العناية القصوى التي تنذلها المعلمات تجاه عملن في حقل التربية و التعليم مقارنة بالمعلمين، وهذا يعد في حد ذاته مؤشرًا و واضحًا لمدى العناية و الإخلاص و الوفاء في عملهن، نظرًا لقلة نوافر البدائل أمامهن للعمل في مجالات

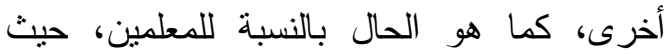

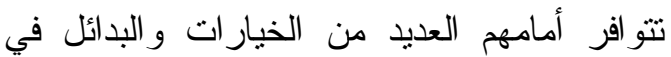
حقول العمل. وبناء عليه يمكن القول، إن حصول الأنثى على وظيفة معلمة هو تحقيق لطموح كانت تتمناه سابقًا، وما عليها إلا الحفاظ عليه من خلال الجهر و الوفاء و الإخلاص في العمل (التعليم)؛ كما قد يعود الأمر إلى أن مهنة التعليم تنتاسب مع الإهل طبيعة المرأة التي ترغب في العمل لساعات محدودة، كي تتفرغ للعناية بشؤون البيت و الأسرة

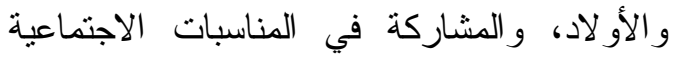
المختلفة. وتتفق هذه النتيجة مع النتيجة التي توصلت إليها غنام (2006) بوجود فروق ذات دلالة إحصائية في الولاء التنظيمي بين المعلمات

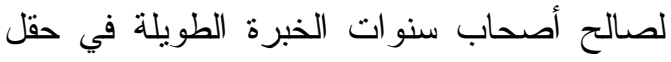
التعليم، وكذلك مع النتيجة التي توصلت إليها السلعوس (2007)، ومفادها أنه توجد فروق دلالة

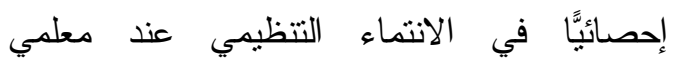
ومعلمات المدارس الخاصة، ولصالح المعلمات. 


\section{التوصيات:}

في ضو ء أهداف الدراسة ونتائجها يوصي الباحث

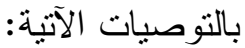

1. تعزيز مستوى الجدية في العمل لاى لإه

المعلمين و المعلمات، و العمل على الحفاظ

عليها وتتميتها باستمر ار .

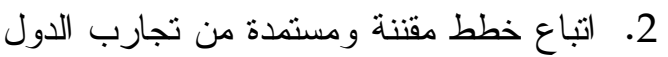

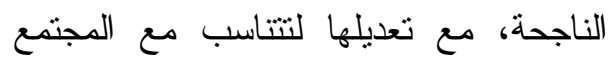

الفلسطيني من أجل تتمية الو لاء لاى العاملين

$$
\text { في حقل التربية و التعليم. }
$$

3. وضع نظام فعال للحوافز و المكافآت المادية

و المعنوية، بما ينعكس إيجابًا على سلوك ولى معلم المدرسة، ويلبي حاجاته وطموحاته.

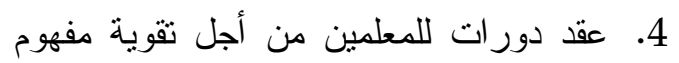

الذات لديهم، ومساعدتهم على تقهم الوضع

الر اهن وتقبله و التعايش معه، وتجاوز أي لي لوني

صعوبات تو اجهمخ في العمل.

5. منح معلمي المدارس صلاحيات أكبر في

اتخاذ القرارات، تشجيعا لهم بعدم الاعتماد

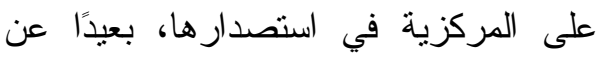
المتابعة و الرقابة الصارمة.

6. عقد دور ات هادفة للمعلمين تتعلق بالعمل في وليه حقل التعليم ونظويره، منل دورات القيادة

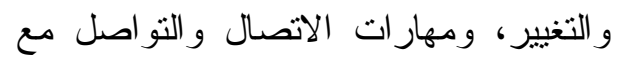

المجتمع، و التخطيط التربوي.

7. إجر اء دراسة مشابهة في الضفئة الغربية وقطاع غزة يتم من خلالها مقارنة نتائج

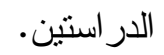

8. إجراء دراسة مقارنة في مستوى الجدية و الو لاء بين المعلمين و المعلمات في المر احل

التدريسية المختلفة.
متغيري النوع الاجتماعي وسنوات الخبرة في مجال السيطرة والتحكم، لصالح المعلمين من أصحاب سنوات الخبرة الطويلة؛ ومتغير سنوات الخبرة والتفاعل بين متغيري النوع الاجتماعي وسنوات الخبرة في الدرجة الكلية للجدية في العمل التزبوي، لصالح المعلمين من أصحاب سنوات الخبرة الطويلة؛ ومتغيري النوع الاجتماعي وسنوات الخبرة في الدرجة الكلية للولاء التنظيمي، ولصالح المعلمات من أصحاب سنوات الخبرة

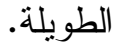

6. إن أعلى مستوى من الجدية في العمل التربوي تمنل في الفقرة التي نصها "لا أجيب عن أي سؤال إلا بعد التأكد من فهمي له"، لهال حيث وصلت النسبة المئوية للاستجابة عليها إلى (86.8\%)، وكان أقل مستوى من الجدية

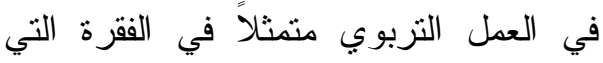
نصها "ليس مهمًّا أن أكون جديَّا في العمل لأن الأمور لا تصبح صحيحة في أي حالٍ من الأحوال"، حيث وصلت النسبة المئوية للاستجابة عليها إلى (41.8\%). 7. إن أعلى مستوى من الولاء النتظيمي تمثل إنل

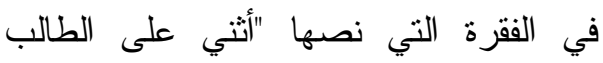

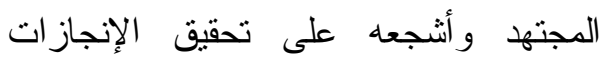
العلية"، حيث وصلت النسبة المئوية للاستجابة عليها إلى (90.2\%)، وكان أقل مستوى من الو لاء التتظيمي متمثناً في الفقرة ولهان

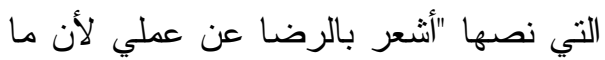

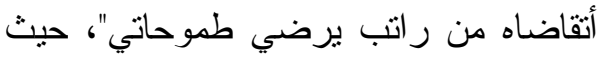
وصلت النسبة المئوية للاستجابة عليها إلى يلى .(\%51.8) 
العملية، دار التقافة للنشر و التوزيع، عمان،

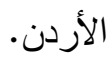

الفهداوي، خليفة؛ و القطاونـــة، أحمــــ (2004).

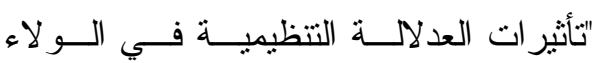

التظظيمي: در اسـة ميدانية للدوائر المركزيــة

في محافظات الجنوب الأردنيـــة". المجلـــة العربية للإدارة، 2(24)، ص.ص: 9-18.

القاروط، صـادق (2006). "الجدية فــي العمــل

وعلاقتها بالرضا الــوظيفي لـــى مـــيري

المدارس الحكومية في محافظـات شــمال الضفة الغربية". رســالة ماجســتير غيــر منشورة، جامعة النجاح الوطنيــة، نــابلس، فلسطين.

مصطفى، ختام (2005). "السمات الشخصــية

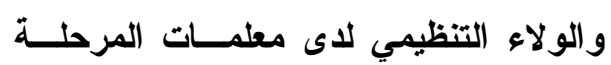
الأسـاسية فــي المــــارس الحكوميــة فـــي محافظة نـابلس"، رســالة ماجســتير غيــر منشورة، جامعة النجاح الوطنيــة، نــابلس، فلسطين.

الموســـوي، ســـنان (2004). إدارة المـــوارد

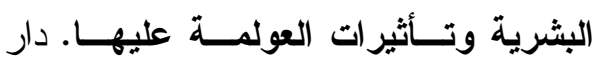
مجدلاوي للنشر و التوزيع، عمــان، الأردن وله
إبر اهيم، وفاء (1996). "ثأثير مستوى مشاركة

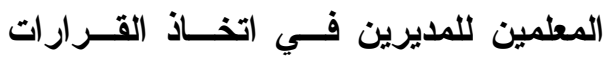
المدرسية على الولاء التنظيمي عند معلمي المدارس الثانوية في محافظة بيث لحــم أريحا". رسالة ماجستير غير منشورة، جامعة النجاح الوطنية، نابلس، فلسطين.

الأحمدي، طلال (2004). "الـــولاء التتظيمـي و علاقته بالخصائص الثخصية و الرغبة فـي

تزرك المنظمة و المهنـــة". المجلـــة العربيـــة للإدارة، 2(24)، ص.ص: صن: 1-44.

البكري، أمل (1990). "درجـــة إدر الك مــديري المدارس الحكومية ومدير اتها للحو افز لزئ

المقدمة لهم، وأثز ذلك بولاههم التتظيمسي".

رسالة ماجستير غيــر منشـــورة، جامعــة اليرموك، إربد، الأردن.

السلعوس، رنا (2007). "العلاقة بين السمات

الثخصية و الانتماء التتظيمي عند معلمـي

المدارس الخاصة في مدينة نابلس". مجلــة

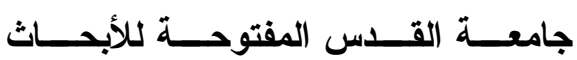
و الدر اسات. (15)، ص.ص: 219-260.

عطوي، جودت (2001). الإدارة المدرسية الحديثة: مفاهيمها النظريــة وتطبيقاتهــــا 


\section{المراجع الأجنبية}

Allred, K., \& Smith, T., (1989). The hardy personality and psychological responses to evaluation threat. Journal of Personality and Social Psychology. 56 (2), p.p:257266.

Brooks, R., (1999). Stressed out of stressed hardy, (Dated in 10 $10^{\text {th }}$ of Jan, 2001). www.drrobertbrooks.com/article.

Enevoldesen, P., \& Dawn, T., (1995). Toward and understanding of three control constructs: personal control, self-efficacy, and hardiness. ERIC, EJ 553129.

Heather, E., \& Gail, F., (1998). Hardiness among elderly women. ERIC, ED 305529 .

Kobasa, S., 91903). Type A and hardiness, Journal of Behavioral Medicine. (6), p.p: 28-31.

Maddi, S., \& Kobasa, S., (1984). The hardy executive, health under stress. Homewood, III, Dow Jones - Irwin.

McNeil, S., Stones, M., \& Hanna, E., (1986). "Measurement of psychological hardiness in older adults". Canadian Journal on Aging. 5(1), p.p: 43-48.

Porter, L., Steers, R., \& Mowday T., (1974). "Organizational commitment, job satisfaction, turnover among psychiatric technicians". Journal of Applied Psychology, 2(6), p.p:59-72.

Qadumi, H., (2001). "Hardiness behavior of English teachers in the northern districts of Palestine". Unpublished Master Thesis, An-Najah National University, Nablus- Palestine.

Reyes, P., \& Imber, M., (1992). "Teachers perceptions of the fairness of their work and their commitment, job satisfaction, and morale: implication for teacher evaluation". Journal of Personal Examination in Education. 3(5), p.p: 291-302. Safici, (1996).

Somech, A., \& Bogler, R., (2002). "Antecedents and consequences of teacher organizational and professional commitment". Educational Administration Quarterly. 38 p.p:555-586.

Thomson, W., (1995). "The contribution of school climate and hardiness to the level of alienation experienced by student teachers". Journal of Education. 88(5), p.p: $269-274$ 